\title{
CLOSURE REPORT \\ FOR UNDERGROUND STORAGE TANK 2310-U \\ AT THE PINE RIDGE WEST \\ REPEATER STATION
}

\author{
OAK RIDGE Y-12 PLANT \\ OAK RIDGE, TENNESSEE \\ FACILITY ID \#0-010117
}

July 1994

Environmental Management Department

Health, Safety, and Environment Organization

\section{Prepared by}

Science Applications International Corporation Under Subcontract 18B-99069C for the

Oak Ridge Y-12 Plant

Oak Ridge, Tennessee 37831

\section{Managed by}

Martin Marietta Energy Systems, Inc.

for the

U.S. Department of Energy

Under Contract No. DE-AC05-84OR21400 


\section{DISCLAIMER}

Portions of this document may be illegible in electronic image products. Images are produced from the best available original document. 


\section{TABLE OF CONTENTS}

LIST OF FIGURES

iv

LIST OF TABLES

LIST OF ACRONYMS

PROFESSIONAL CERTIFICATION

OWNER/OPERATOR CERTIFICATION

EXECUTIVE SUMMARY

\section{CLOSURE REPORT}

1.0 INTRODUCTION

1.1 PURPOSE AND SCOPE.

$1-1$

1.2 SITE DESCRIPTION

$1-1$

1.3 GEOLOGICAL AND HYDROGEOLOGICAL SETTING .

1.3.1 Site Geology

1.3.2 Site Surface Water and Groundwater

2.1) PREVIOUS INVESTIGATIONS

2.1 INITIAL ABATEMENT ACTIVITIES

2.2 TANK REMOVAL/INITIAL SITE CHARACTERIZATION

2.3 FREE-PRODUCT RECOVERY INVESTIGATION

2.4 SITE INVESTIGATION

2.5 INITIAL VERTICAL CONTAMINATION EXTENT SAMPLING

$2-6$

$2-6$

2.6 ADDITIONAL VERTICAL CONTAMINATION EXTENT SAMPLING

2.7 EVALUATION OF DATA FROM PREVIOUS INVESTIGATIONS

3.0 SOIL CORRECTIVE ACTION PROGRESS AND PROBLEMS ............................... 3- 3-1

3.1 INITIAL CORRECTIVE ACTION ACTIVITIES …....................................

3.1.1 Initial Excavation .............................................................................

3.1.2 Initial Contirmatory Sampling ………………………………………...

3.1.3 Results of Initial Confirmatory Sampling............................................... 3-1

3.2 SECOND EXCAVATION AND CONFIRMATOR Y SAMPLING ……….......

3.2.1 Final Sampling Results .........................................................................

4.0) SUMMARY AND CONCLUSIONS ……..........................................................

5.0) REFERENCES ..........................................................................................

APPENDIXES

A LETTER FROM R.J. SPENCE T() E.C. LEMING

A-1

B LETTER FROM J. HARLESS TOR.J. SPENCE

C INITIAL EXCAVATION NOTES

D SECOND EXCAVATION NOTES

E INITIAL CONFIRMATORY SAMPLING LAB DATA SHEETS

F SECOND CONFIRMATORY SAMPLING LAB DATA SHEETS

B-1

C-1

D-1

E-1

F-1 


\section{LIST OF FIGURES}

1.1 Location of the Pine Ridge West Repeater Station Site at the Y-12 Plant .................. $\quad 1-2$

$1.2 \quad$ Pine Ridge West Repeater Station site map ............................................................... $1-3$

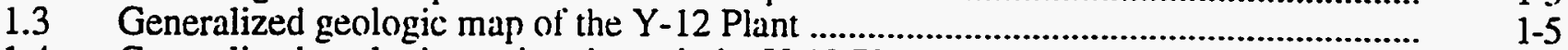

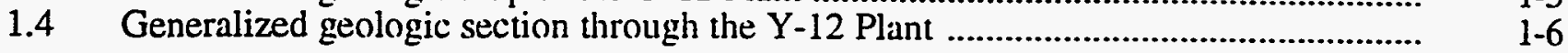

2.1 Pine Ridge West Repeater Station previous investigation soil sampling locations

3.1 Initial corrective action excavation and confirmatory soil sampling locations at the Task 2310-U Site

3.2 Second corrective action excavation and confirmatory soil sampling locations at the Task 2310-U Site

\section{LIST OF TABLES}

2.1 Chronological summary of events: Tank 231()-U, Pine Ridge West

Repeater Station

2.2 Summary of analytical dala collected from previous investigations at the UST 2310-U Site

3.1 Analytical results for confirmatory soil samples collected during initial corrective action excavation activities at the Tank 2310)-U Site, April 8, 1994

3.2 Analytical results for confirmatory soil samples collected during additional 


\section{ACRONYMS}

BGS below ground surface

BTEX

BTX

benzene, toluene, ethylhenzene, and xylenes

EAR/CAP

benzene, toluene, and xylenes

GC gas chromatograph

Environmental Asssessment and Corrective Action Plan for Underground Storage

ISC

OVM

TDEC

TDG

TPH

TPH-GRO

UST

Initial Site Characterization

organic vapor meter

Tennessee Department of Environment and Conservation

Technical Guidance Document

total petroleum hydrocarbons

total petroleum hydrocarhons - gasoline range organics

underground storage tank 


\section{SIGNATURE PAGE}

I certify under penalty of law, including but not limited to penalties for perjury, that the information contained in this report and on any attachments, is true, accurate and complete to the best of my knowledge, information, and belief. I am aware that there are significant penalties for submitting false information, including the possibility of fine and imprisonment for intentional violations.

See Attached Certification

Owner/Operator (Print)

William D. Keefer

P.E. or P.G. (Print)

Wilkin OPleghatin3328

Signature TN Lic./Reg. \#

$717 / 94$

Date

If a P.E. signs this report, please indicate the area of expertise.

(Print or Type)

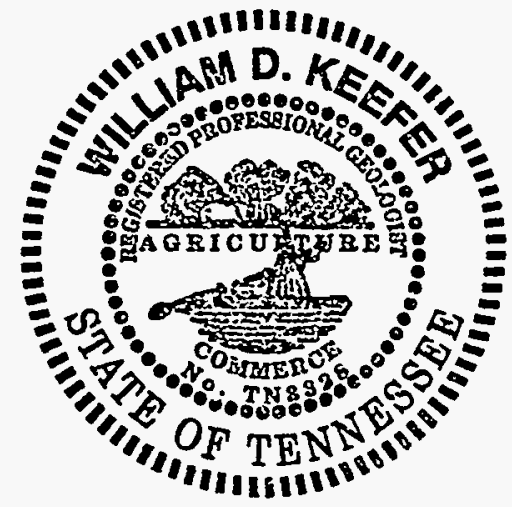

(P.E./P.G. Stamp/Seal)

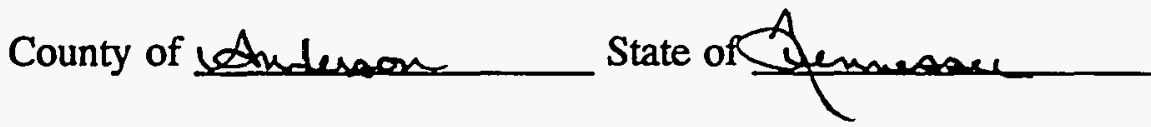

Subscribed and Sworn to before me this

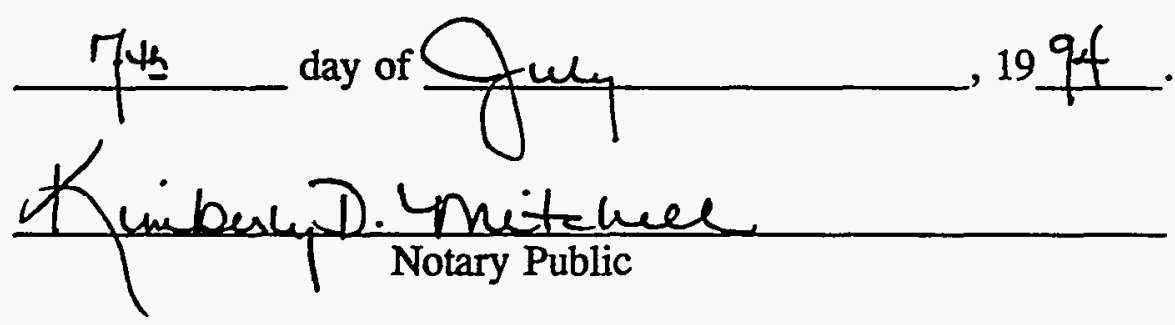




\section{CLOSURE REPORT \\ FOR UNDERGROUND STORAGE TANK 2310-U \\ AT THE PINE RIDGE WEST \\ REPEATER STATION}

I certify that this document and all enclosures were prepared under my direction or supervision in accordance with a system designed to ensure that qualified personnel properly gather and evaluate the information submitted. Based on my inquiry of the person or persons directly responsible for gathering the information, the information submitted is, to the best of my knowledge and belief, true, accurate, and complete.

U.S. Department of Energy

Owner and operator

By:

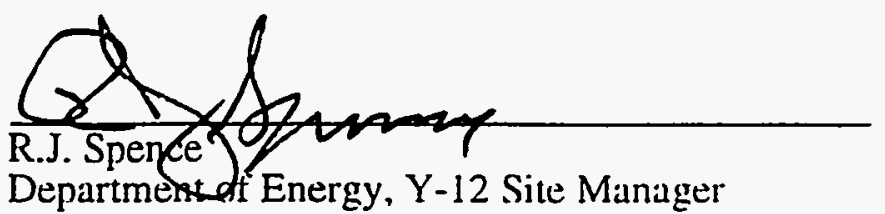

Martin Mariettu Energy Systems, Inc.

Co-Operator

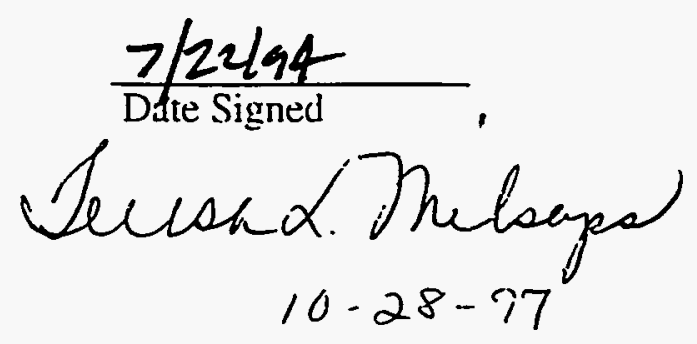

By:
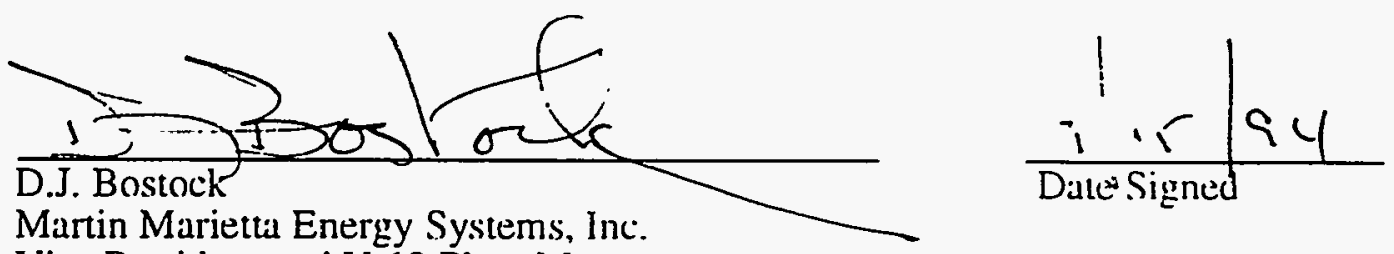

Vice President and Y-12 Plant Manager

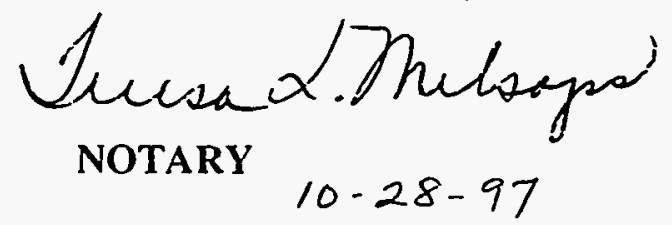

(Stamp/Seal)

Note: Both signatures have been nolari\%ed per reyuirements. 


\section{EXECUTIVE SUMMARY}

This document represents the Closure Report for Underground Storage Tank (UST) 2310-U at the Pine Ridge West Repeater Station, Oak Ridge Y-12 Plant, Oak Ridge, Tennessee. Tank 2310-U was a 20()-gal gasoline UST which serviced the emergency generator at the Repeater Station. The tank was situated in a shallow tank bay adjacent to the Repeater Station along the crest of Pine Ridge. The tank failed a tightness test in October 1989 and was removed in November 1989. The purpose of this report is to document completion of soil corrective action, present supporting analytical data. and request closure for this site.

The UST 2310-U site has been the subject of four separate environmental investigations to define the nature and extent of petroleum contamination. The results of these investigations indicated that petroleum contamination was present in soils within and immediately adjacent to the former tank bay. These investigations also indicaled that petroleum contamination had not migrated to bedrock nor potentially impacted groundwater. The groundwater table is estimated to be between 180) and 230 fit helow the crest of Pine Ridge. The seep is to the east and is $137 \mathrm{ft}$ below the crest of Pine Ridge.

Following completion of these investigations, soil corrective action was initiated in accordance with the approved Corrective Action Plan. Potentially contaminated soils were excavated, and field screening was used to direct and determine the extent of soil removal. Confirmatory soil samples were collected from the excavation and submitted for analysis. Two rounds of excavation were required to delimit and remove petroleum-contaminated soil above the applicable Tennessee Department of Environment and Conservation (TDEC) Closure Action Level.

Approximately $59 \mathrm{yd}^{3}$ of contaminaled soil were excavated and removed from the UST 2310-U site. This soil is staged at the (19)10 Pumphouse Area at the west end of the Y-12 Plant and enclosed in plastic. This soil will he properly characterized, treated, and/or disposed in accordance with applicable TDEC guidance. Pending completion of these activities, TDEC will be notified of the disposition of the waste soil. Because corrective action at the UST 2310-U site has been completed, closure of the site is requested in accordance with the requirements of Rule 12(K)-1-15-.(16. 


\subsection{INTRODUCTION}

\subsection{PURPOSE AND SCOPE}

This document represents the Closure Report for Underground Storage Tank (UST) 2310-U at the Pine Ridge West Repeater Station, Oak Ridge Y-12 Plant, Oak Ridge, Tennessee. The primary purpose of this report is to document the completion of removal of petroleum-contaminated soil in accordance with the Corrective Action Plan and to report the results of confirmatory soil sampling. This document also summarizes environmental assessment and other investigatory activities conducted at the site.

The corrective action implemented at the site has consisted of overexcavation of the former tank pit and the collection of soil samples to confirm that all petroleum-contaminated soil above the applicable action levels has been removed. Based on previous investigations, which have shown that petroleum contamination has not migrated to bedrock below the tank pit and approval by the Tennessee Department of Environment and Conservation (TDEC), no groundwater remediation or monitoring activities have been conducted [letter from James Harless to Robert Spence, dated December 6, 1993 (Appendix B)].

This document has been prepared in accordance with the requirements of TDEC Rule 1220-1-15 and in accordance with applicable portions of Technical Guidance Document (TGD) (K)7 contained in the TDEC UST Reference Handbook, Second Edition (TDEC 1994).

This document is organized into four sections. Section 1 presents introductory information relative to the site including regulatory initiative, site geography, and a description of the site geology and hydrogeology. Section 2 summarizes previous investigations conducted at the site. Section 3 details implementation of corrective action at the site and provides the results of confirmatory sampling. Section 4 summarizes sampling results and provides conclusions and recommendations regarding UST 2310-U.

\subsection{SITE DESCRIPTION}

Tank 2310-U is located at the Pine Ridge West Repeater Station which is located north of the Oak Ridge Y-12 Plant on Pine Ridge near the Y-12 Plant Water Treatment Facility (Figures 1.1 and 1.2). The site is at an elevation of $\sim 1180 \mathrm{ft}$. The $\mathrm{Y}-12$ Plant is located south of Oak Ridge, Tennessee. Maps of the area include two north arrows, a true north and a plant-grid north, with most maps oriented relative to plant north.

Tank 2310-U was a 200 -gal gasoline UST that serviced an infrequently operated emergency generator located inside the Pine Ridge West Repeater Station. The generator provided power to the station during power outages and for weekly tests. The tank is estimated to have been filled once a year. Because UST 2310-U was in use when the Y-12 Plant last received delivery of leaded gas in February 1975, the tank probably contained leaded gasoline during its early years of use.

According to the Initial Abatement Report, UST 2310-U is at least 25 years old. There are no known engineering drawings of the tank, nor are any historical details of tank installation or maintenance records available. However, observations during tank removal indicated that the tank rested in an unlined pit on a clay, sand, and gravel pad. The pit was $\sim 4 \mathrm{ft}$ deep and was backfilled with soil. Only the fill-pipe and the vent pipe were exposed above ground. One service line, $-6 \mathrm{ft}$ in length, connected the tank to the emergency generator located inside the Repeater Station. 


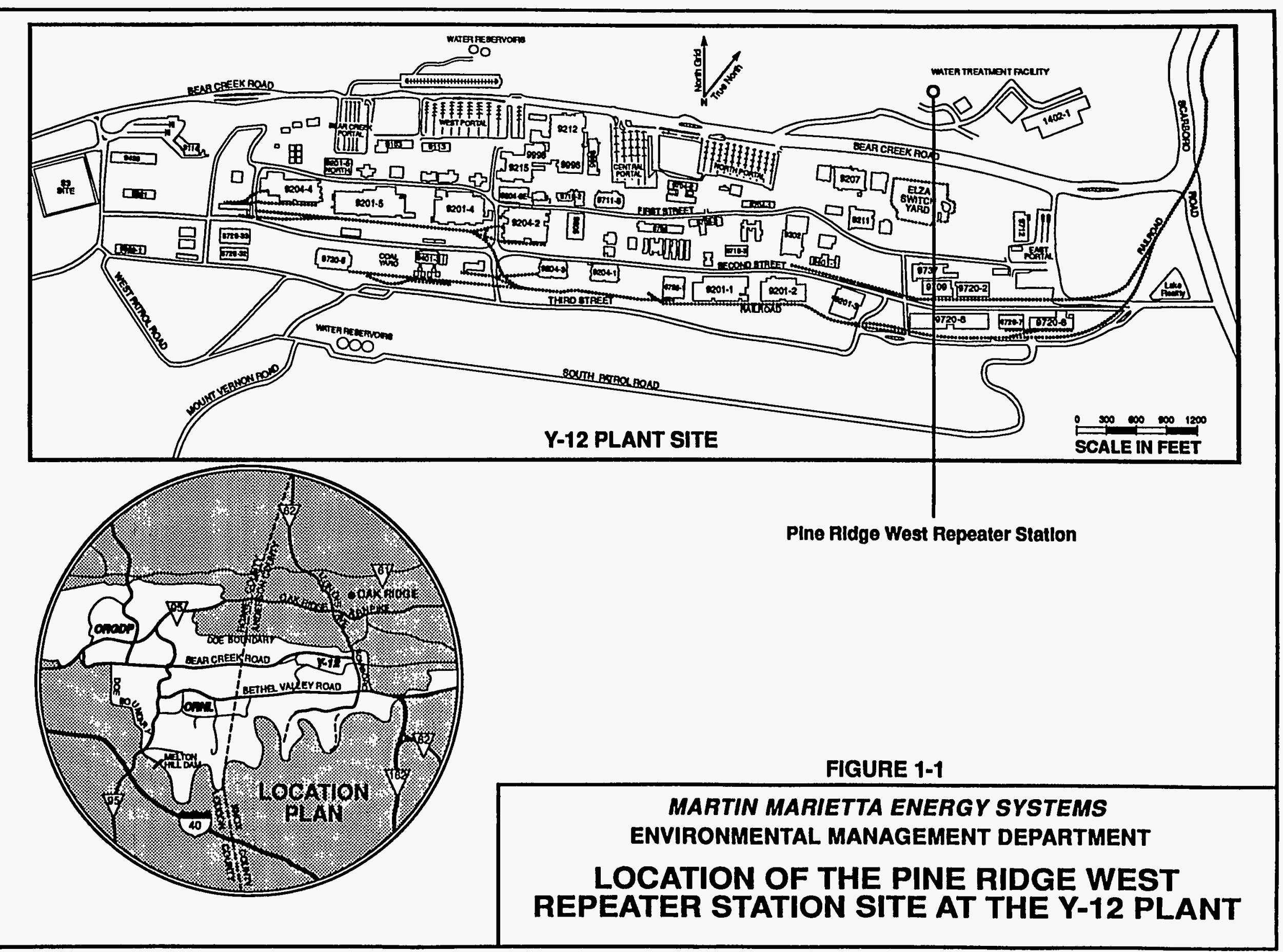




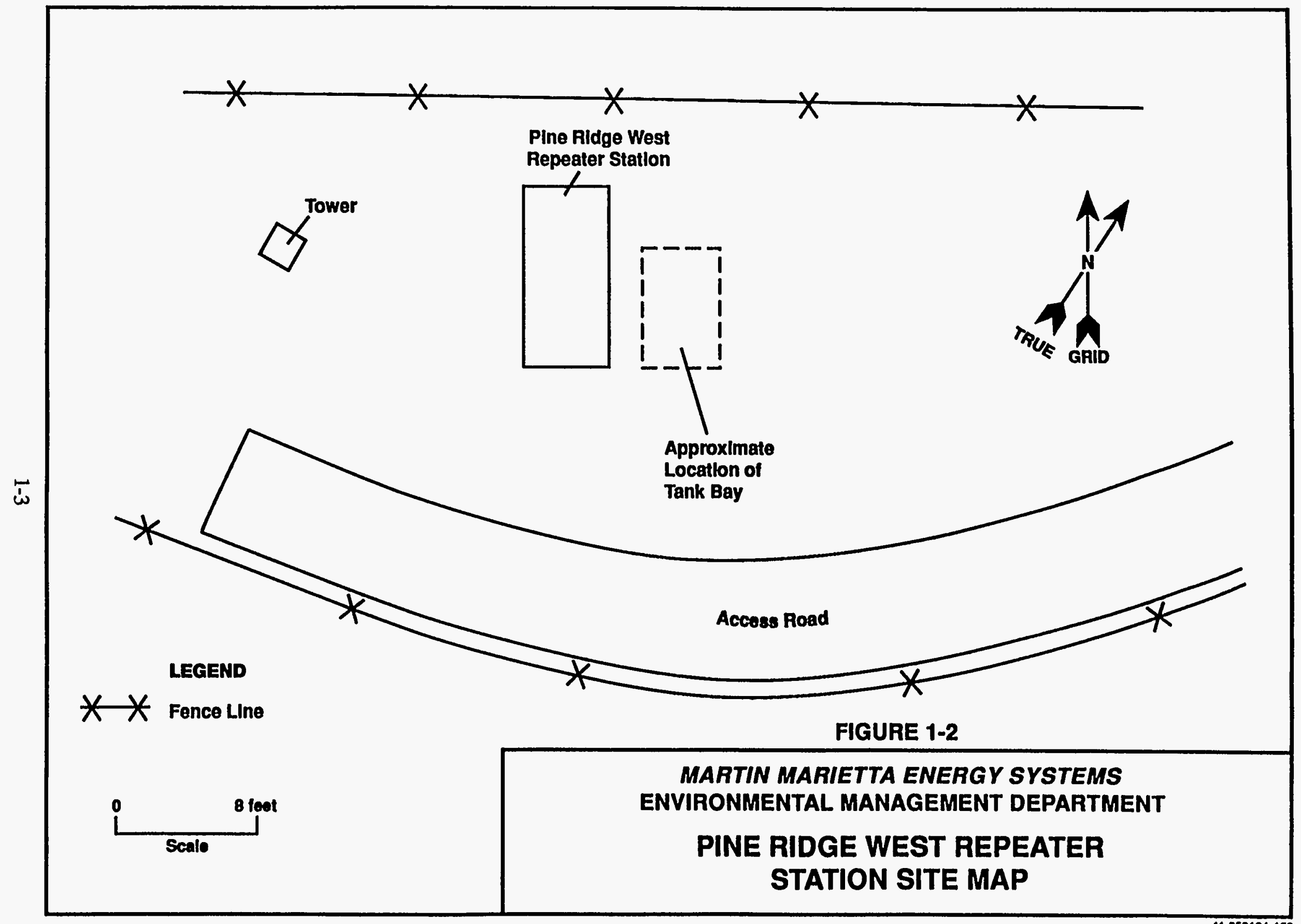




\subsection{GEOLOGICAL AND HYDROGEOLOGICAL SETTING}

\subsubsection{Site Geology}

The Y-12 Plant is located in Bear Creek Valley in the southern part of the Valley and Ridge Physiographic province. This province is characterized by narrow elongate ridges and valleys trending northeast-southwest. Resistant sandstone, siltstone, and siliceous limestone typically form ridges while valleys are commonly underlain by less resistant shale and soluble carbonate.

The bedrock units in the vicinity of the Y-12 Plant range from Cambrian to Ordovician age. These strata have been classified into groups and formations based on age, lithology, and fossil assemblages. From oldest to youngest, the bedrock units are the Rome Formation, Conasauga Group, and Knox Group. The main Y-12 Plant area is underlain by limestone, shale, and siltstone of the Conasauga Group. Sandy shale and siltstone of the Rome Formation underlie Pine Ridge to the north, and siliceous dolostones of the Knox Group underlie Chestnut Ridge to the south. The bedrock units are overlain by unconsolidated deposits of varying thickness (10-30 ft) and composition but generally consist of man-made fill, alluvium, colluvium, and in-situ weathered bedrock (residuum).

Formations in Bear Creek Valley strike N47"E to N67"E and dips vary between 30"SE and nearly vertical. Joint sets are a common feature of the strata in Bear Creek Valley. Several studies of joints have indicated that their orientations and spacings are quite variable. However, each of these studies identified at least one major joint set that roughly parallels geologic strike and dip (Geraghty \& Miller, Inc. 1986). Small-scale folds, associated with thrust faulting, are common in the Conasauga Group and Rome Formation, which contribute to the various bedding orientations in these units (Rothschild et al. 1984).

The UST 2310-U site at the Pine Ridge West Repeater Station is underlain by the Rome Formation (Figures 1.3 and 1.4). The thickness of the Rome Formation in this area is not known because no subsurface investigation has completely penetrated the unit in this area to date. The uppermost $100 \mathrm{ft}$ of the Rome Formation consists of massive- to thinly bedded silty mudstone and shale (King and Haase 1987). The Rome Formation is overlain by the Pumpkin Valley Shale and is truncated by the White Oak Mountain Thrust Fault $\sim 600 \mathrm{ft}$ north of the site.

Soils in the vicinity of the Y-12 Plant are typically silty loams, varying in color and thickness. The soils on top of Pine Ridge are part of the Lehew loam unit. This unit is characterized by a surface layer that is dark brown to reddish brown and up to $3 \mathrm{ft}$ thick. The underlying subsoil is reddish brown, slightly gravelly, and also $3 \mathrm{ft}$ thick. These soils tend to be low in available water capacity and have moderate permeabilities (Moneymaker 1981).

\subsubsection{Site Surface Water and Groundwater}

The Pine Ridge West Repeater Station is located on a topographic high. As a result, surface water in the area drains away from the sile, ultimately to the Y-12 Plant storm sewer system adjacent to the base of the southern flank of Pine Ridge along Bear Creek Road.

The groundwater hydrology of the UST 2310-U site is not well defined. There have been no studies done at the site, and the nearest monitoring wells are located in Bear Creek Valley. The exact depth to the water table is not known, but may be estimated from the elevation of the water table in wells GW-189 and GW-199. located in Bear Creek Valley, and from the elevation of springs near the site. On the north side of Pine Ridge, the water table crops out at a spring at $\sim 980 \mathrm{ft}$ in elevation. In monitoring wells GW-198 and GW-199 south of Pine Ridge, the elevation of the water table has been measured at $\sim 95() \mathrm{ft}$. This information suggests that the water 


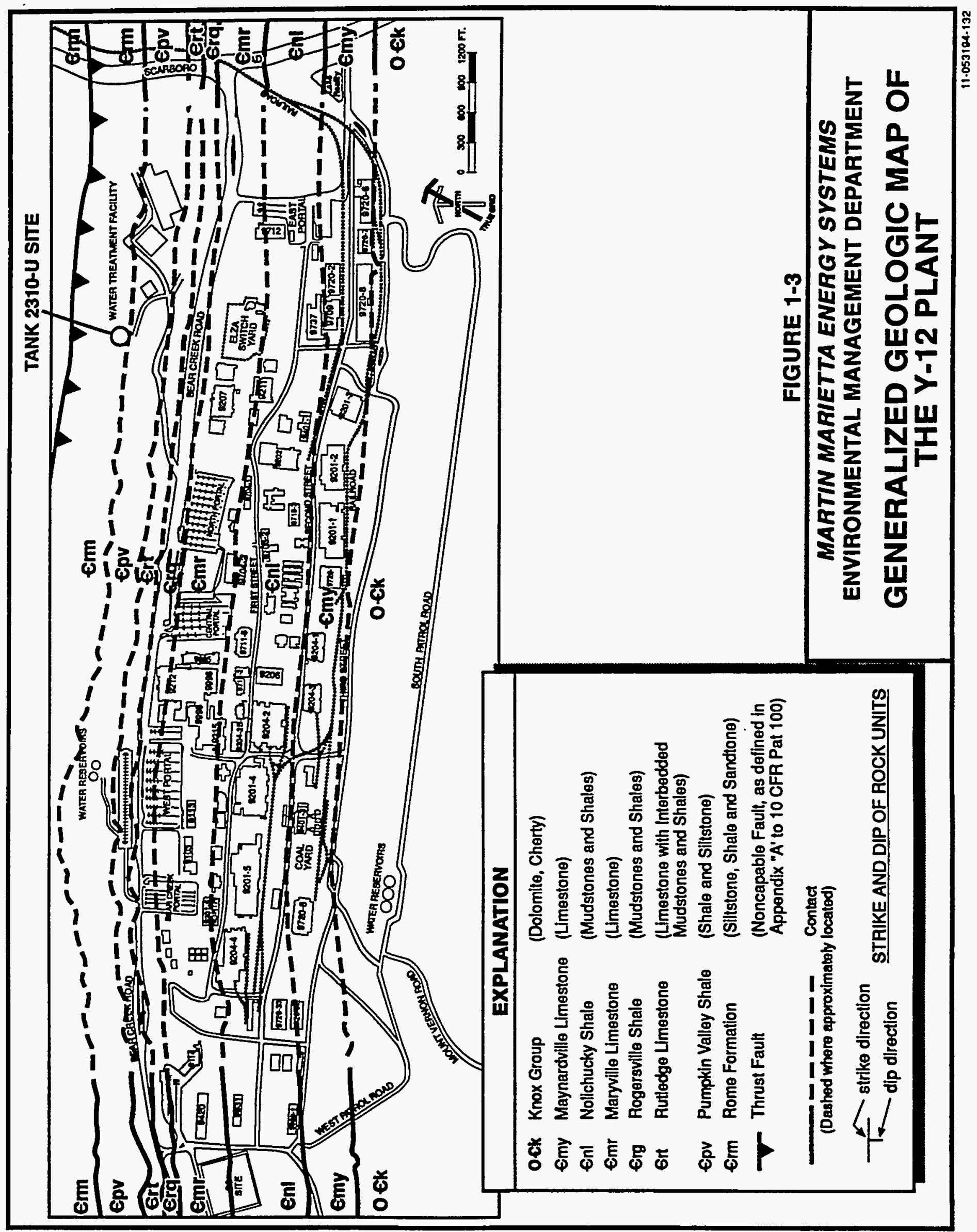




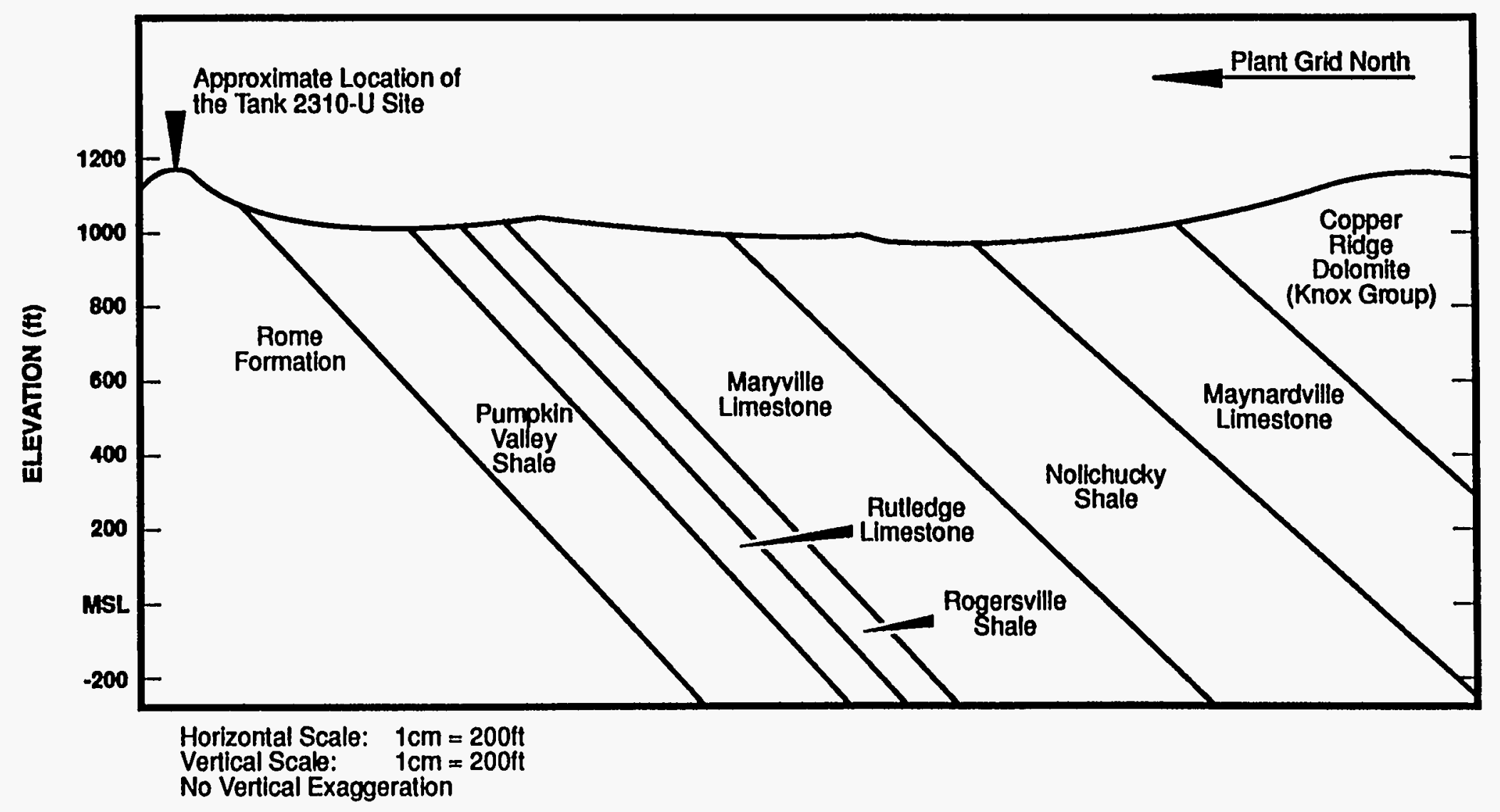

FIGURE 1-4

Reference: King and Haase, 1987.

MARTIN MARIETTA ENERGY SYSTEMS ENVIRONMENTAL MANAGEMENT DEPARTMENT

GENERALIZED GEOLOGIC SECTION THROUGH THE Y-12 PLANT 
table at the Pine Ridge Site lies somewhere between 1000 and $950 \mathrm{ft}$ in elevation (180 to $230 \mathrm{ft}$ below land surface). The seep is to the east and is $137 \mathrm{ft}$ below land surface. No perched water tables have been identified above the main water table in this area of Pine Ridge. However, localized perched zones may exist along the crest of the ridge at the contact between soil and bedrock. These perched zones, if present, are not anticipated to be of significant areal extent because of the narrow width of the ridge top. 


\subsection{PREVIOUS INVESTIGATIONS}

This section provides a reconstruction of investigations and activities conducted at the Pine Ridge West UST 2310-U site prior to the implementation of corrective actions. A chronological summary of this information is also provided in Table 2.1.

\subsection{INITIAL ABATEMENT ACTIVITIES}

Tank 2310-U was first suspected of leaking on October 31, 1989, following a 24-h static test. The Equipment Testing and Inspection Report that was completed following the test is presented in Appendix A of the approved Environmental Assessment and Corrective Action Plan for Underground Storage Tank 2310-U, Pine Ridge West Repeater Station, Energy Systems 1993, Y/SUB/93-99928C/Y20/2 (hereafter referred to as the EAR/CAP for the site).

Because UST 2310-U was suspected of leaking, Y-12 Plant personnel decided to remove it as part of the Y-12 UST Program. To ensure uninterrupted radio communications, the tank could not be removed from service until it could be replaced by a temporary storage tank. During this delay, on November 1,1989 , the liquid level in the tank was checked and found to have remained at the same level as the previous day (just below the fill pipe). Between November 1 and November 8, 1989, arrangements were made for the tank to be emptied and removed. On November 8, 1989, the tank was again checked by Y-12 Plant personnel and found to be empty. No documentation of the personnel responsible for the removal of the fuel has been identified and, as a result, the fuel removal/transfer is unconfirmed yet considered probable. This conclusion is supported by the operational history of the tank and the tightness test conducted on October 31,1989, which do not indicate that rapid loss of product would have occurred from the tank. Additional information concerning initial abatement activities conducted at the Pine Ridge West Repeater Station Site is presented in Appendix $B$ of the EAR/CAP for the site.

\subsection{TANK REMOVAL/INITIAL SITE CHARACTERIZATION}

Excavation of UST 2310-U at the Pine Ridge West Repealer Stalion area was started on November 17, 1989. The tank was removed, temporarily stored, then transported to the Y-12 Plant Waste Management Storage Yard for disposal by property sale as scrap metal (Appendix $C$ of the EAR/CAP). Inspection of the tank revealed several small holes on one side just above the midline and one hole on the bottom just below the fill pipe.

Immediately following excavation of the tank, soil samples were collected from four locations within the tank pit (labeled 1, 2, 3, and 4 on Figure 2.1) as part of the Initial Site Characterization (ISC). Samples were collected from 1- and 3-ft depths below the bottom of the pit. The two samples from each hole were combined into a single composite sample, with split samples taken for laboratory analyses. An additional soil sample was collected from the excavated soil placed adjacent to the pit (labeled 5 on Figure 2.1).

Soil samples collected during the ISC were analyzed for benzene, toluene, and xylenes (BTX) and lead. Analysis for total petroleum hydrocarbons (TPH) was not conducted because this analytical parameter was not required by TDEC for gasoline UST site soil samples at the time of the UST 231()-U removal. Analytical results for the ISC are summarized in Table 2.2. The laboratory analytical results for these samples are presented in Appendix D of the EAR/CAP for the site. The presence of BTX levels in excess of the most stringent TDEC Closure Action Level for soils $(62.00 \mathrm{ppm}-$ Sample 1) indicaled that further investigation would be necessary at the site. 
Table 2.1. Chronological summary of events: Tank 2310-U, Pine Ridge West Repeater Station

October 31, 1989

November 17, 1989

July 1990

February 19 and 20, 1992

February 1993

October 5, 1993

October 14, 1993

December 6, 1993

December 30, 1993

April 8, 1994

May 5, 1994
Tank 2310-U first suspected of leaking following a 24-h static test.

Tank 2310-U excavated and removed. Initial site characterization conducted.

Site investigation conducted.

Initial Vertical Extent of Soil Contamination Study conducted.

Environmental Assessment Report and Corrective Action Plan (EAR/CAP) for Tank 2310-U issued (Y/SUB/93-99928C/Y20/2).

TDEC requests additional data for the interval. $7.0 \mathrm{ft}$ BGS to hedrock. below the former Tank 2310-U pit.

Second Vertical Extent of Soil Contamination Study conducted.

TDEC issues notification indicating that no further groundwater investigative activities are required at the UST 2310-U site.

The EAR/CAP for the UST 231()-U site is approved by TDEC.

Initial corrective action excavation and confirmatory sampling is conducted.

Second round of corrective action excavation and confirmatory sampling is conducted. 


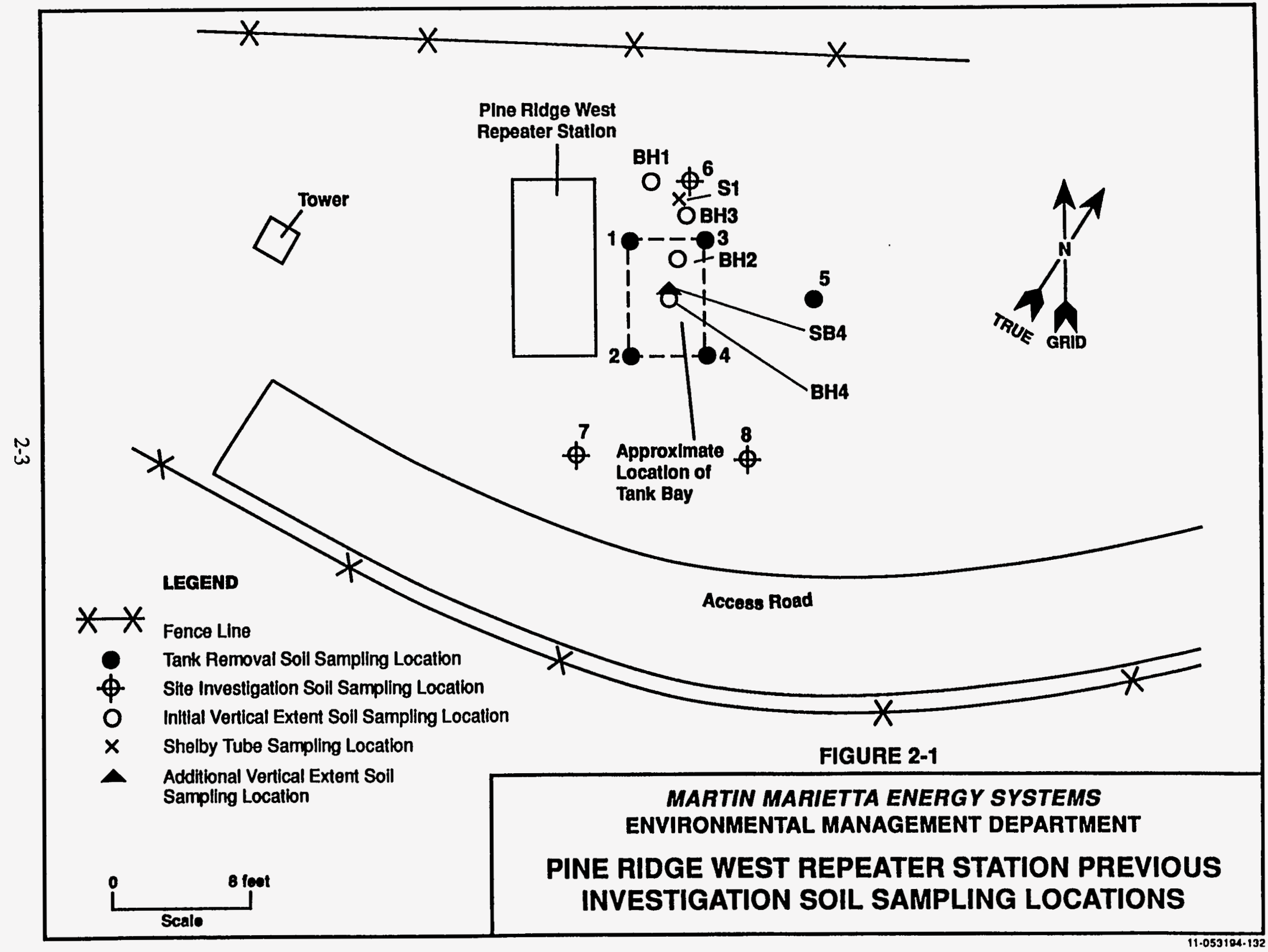


Table 2.2. Summary of analytical data collected from previous investigations at the UST $2310-U$ site

\begin{tabular}{|c|c|c|c|c|c|c|c|c|c|}
\hline $\begin{array}{c}\text { Investigation/ } \\
\text { sample } \\
\text { number- } \\
\text { location } \\
\end{array}$ & $\begin{array}{r}\text { Parameter: } \\
\text { units: }\end{array}$ & $\begin{array}{l}\text { Lead' } \\
\text { ppm }\end{array}$ & $\begin{array}{c}\text { Benzene? } \\
\text { ppm }\end{array}$ & $\begin{array}{c}\text { Ethyl- } \\
\text { benzene } \\
\text { ppm }\end{array}$ & $\begin{array}{c}\text { Toluene }^{2} \\
\text { ppm }\end{array}$ & $\begin{array}{c}\text { Xylenes }^{2} \\
\text { ppm }\end{array}$ & $\begin{array}{c}\text { Substituted } \\
\text { benzene } \\
\text { ppm }\end{array}$ & $\begin{array}{l}\text { TPH } \\
\mathrm{ppm}\end{array}$ & $\begin{array}{c}\text { Total } \\
\text { BTEX } \\
\text { ppm }\end{array}$ \\
\hline
\end{tabular}

Tank removal/initial site characterization

Sample 1
Sample 2
Sample 3
Sample 4
Sample 5
(waste pile)


Boring 6
$5.0-5.4 \mathrm{ft}$
Boring 7
$4.0-4.5 \mathrm{ft}$
Boring 8
$5.0-5.3 \mathrm{ft}$
$10.0-11.5 \mathrm{ft}$
$15.0-16.0 \mathrm{ft}$
$20.0-20.8 \mathrm{ft}$

BH-1

$5.0-7.5 \mathrm{ft}$

$10.0-12.5 \mathrm{ft}$

$15.0-16.0 \mathrm{ft}$

BH-2

$6.0-7.0 \mathrm{ft}$

BH-3

$5.0-7.5 \mathrm{ft}$

$12.5-15.0 \mathrm{ft}$

$16.0-17.0 \mathrm{ft}$

$\begin{array}{ll}2.650 \mathrm{~J}^{4} & 1.490 \mathrm{~J} \\ 0.331 & 0.952 \mathrm{~J} \\ 0.872 \mathrm{~J} & 0.311 \mathrm{~J} \\ 0.054 & 0.308 \\ 0.018 & 0.122\end{array}$

$3.670 \mathrm{~J}$

$<0 .(150$

$0.050 \mathrm{U}^{5}$
20.840J
$15.360 \mathrm{~J}$
$5.160 \mathrm{~J}$
0.019

$0.05(0 \mathrm{U}$

$28.290 \mathrm{~J}$
$25.190 \mathrm{~J}$
$12.290 \mathrm{~J}$
$9.840 \mathrm{~J}$
$4.200 \mathrm{~J}$

$\begin{array}{cc}- & * 62.00 \mathrm{~J}^{3} \\ Z & 46.00 \mathrm{~J}^{3} \\ - & 16.00 \mathrm{~J}^{3} \\ - & 15.00 \mathrm{~J}^{3} \\ - & 4.400 \mathrm{~J}^{3}\end{array}$

Site investigation

\begin{tabular}{|c|c|c|c|c|c|c|c|}
\hline 7.4 & $.010 \mathrm{U}$ & $.010 \mathrm{U}$ & $.010 \mathrm{U}$ & .0100 & - & $\mathrm{ND}^{6,7}$ & $\mathrm{ND}^{8}, 10$ \\
\hline 19 & $.010 \mathrm{U}$ & $.010 \mathrm{U}$ & $.010 \mathrm{U}$ & $.010 U$ & - & $\mathrm{ND}^{6,7}$ & $\mathrm{ND}^{8,10}$ \\
\hline 34 & $.010 U$ & $.010 U$ & $.010 \mathrm{U}$ & $.010 U$ & - & $\mathrm{ND}^{6,7}$ & $\mathrm{ND}^{8,10}$ \\
\hline 25 & $.010 \mathrm{U}$ & $.010 \mathrm{U}$ & $.010 U$ & $.010 U$ & & $\mathrm{ND}^{6,7}$ & $\mathrm{ND}^{8,10}$ \\
\hline 19 & $.010 \mathrm{U}$ & $.010 \mathrm{U}$ & $.010 \mathrm{U}$ & .010U & 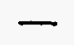 & $\mathrm{ND}^{6,7}$ & $\mathrm{ND}^{8,10}$ \\
\hline 30 & $.010 \mathrm{U}$ & $.010 \mathrm{U}$ & $.010 \mathrm{U}$ & $.010 \mathrm{U}$ & - & $\mathrm{ND}^{6,7}$ & $\mathrm{ND}^{8,10}$ \\
\hline
\end{tabular}

Initial vertical contamination extent sampling

$\begin{array}{ccccr}9.0 & 0.013 \mathrm{U} & 0.013 \mathrm{U} & 0.013 \mathrm{U} & 0.013 \mathrm{U} \\ 4.8 & 0.013 \mathrm{U} & 0.013 \mathrm{U} & 0.013 \mathrm{U} & 0.013 \mathrm{U} \\ 2.6 & 0.012 \mathrm{U} & 0.012 \mathrm{U} & 0.012 \mathrm{U} & 0.012 \mathrm{U} \\ & & & & \\ \text { NA }^{\prime \prime} & \mathrm{NA} & \mathrm{NA} & \mathrm{NA} & \mathrm{NA} \\ & & & & \\ 23.0 & 0.012 \mathrm{U} & 0.012 \mathrm{~J} & 0.012 \mathrm{~J} & 0.012 \mathrm{~J} \\ 80.0 & 0.012 \mathrm{U} & 0.012 \mathrm{~J} & 0.012 \mathrm{~J} & 0.012 \mathrm{~J} \\ 4.4 & 0.012 \mathrm{U} & 0.012 \mathrm{~J} & 0.012 \mathrm{~J} & 0.012 \mathrm{~J}\end{array}$

$\begin{array}{cr}5.0 U^{9} & \text { ND }^{8}, 10 \\ 5.0 U^{9} & \text { ND }^{8,10} \\ 5.0 U^{9} & \text { ND }^{8.10} \\ 3400^{9} & \text { NA } \\ 37.0^{9} & \text { ND }^{8.10} \\ 5.0 U^{9} & \text { ND }^{8.10} \\ 5.0 U^{9} & \text { ND }^{8.10}\end{array}$


Table 2.2 (continued)

\begin{tabular}{|c|c|c|c|c|c|c|c|c|c|}
\hline $\begin{array}{c}\text { Investigation/ } \\
\text { sample } \\
\text { number- } \\
\text { location } \\
\end{array}$ & $\begin{array}{r}\text { Parameter: } \\
\text { units: }\end{array}$ & $\begin{array}{r}\text { I.ead }^{1} \\
\text { ppm }\end{array}$ & $\begin{array}{c}\text { Benzene? } \\
\text { ppm }\end{array}$ & $\begin{array}{c}\text { Eithyl- } \\
\text { benzene? } \\
\text { ppm }\end{array}$ & $\begin{array}{c}\text { Toluene }{ }^{2} \\
\text { ppm }\end{array}$ & $\begin{array}{c}\text { Xylenes }^{2} \\
\text { ppm }\end{array}$ & $\begin{array}{c}\text { Substituted } \\
\text { benzene? } \\
\text { ppm }\end{array}$ & $\begin{array}{l}\text { TPH } \\
\text { ppm }\end{array}$ & $\begin{array}{c}\text { Total } \\
\text { BTEX } \\
\text { ppm } \\
\end{array}$ \\
\hline \multicolumn{10}{|c|}{ Additional vertical contamination extent sampling } \\
\hline $\begin{array}{l}\text { SB-4 } \\
7.0-9.5 \mathrm{ft} \\
9.5-12.0 \mathrm{ft} \\
12.0-17.0 \mathrm{ft} \\
17.0-19.3 \mathrm{ft}\end{array}$ & & $\begin{array}{c}22 \\
10 \\
62 \\
1.1\end{array}$ & $\begin{array}{l}\text { NA } \\
\text { NA } \\
\text { NA } \\
\text { NA }\end{array}$ & $\begin{array}{l}\text { NA } \\
\text { NA } \\
\text { NA } \\
\text { NA }\end{array}$ & $\begin{array}{l}\text { NA } \\
\text { NA } \\
\text { NA } \\
\text { NA }\end{array}$ & $\begin{array}{l}\text { NA } \\
\text { NA } \\
\text { NA } \\
\text { NA }\end{array}$ & & $\begin{array}{c}<0.5^{12} \\
<0.5^{12} \\
24^{12} \\
<0.5^{12}\end{array}$ & $\begin{array}{l}<0.020 \\
<0.020 \\
<1.25 \\
<0.0205\end{array}$ \\
\hline
\end{tabular}

* Indicates contaminant level greater than the inost stringent IIDEC Closure Action Level for Soil.

1 Method: Atomic absorption, graphite furnace technique (liPA, March 1985).

2 Purge and trap GC/MS, 8250 (I:PA, November 1986).

3 Sum of benzene, ethylbenzene, loluene, xylenes, and substituted txinzenes.

4 J-Estimated value.

5 U-Contaminant not detected during the analysis.

6 Method: Modified Fourier Transform Infrared spectrometry (EPA, March 1985).

7 ND-Results of the TPH analysis were below detection.

N 8 Sum of benzene, toluene, ethylbenzene, and xylenes.

9 Modified purge and trap GC/MS (EPA, November 1986).

10 ND-All components of the BTEX summation were below detection.

11 No analysis performed.

12 Total Petroleum Hydrocarbons-Gasoline Range Organics, TN Method. 


\subsection{FREE-PRODUCT RECOVERY INVESTIGATION}

Because the Pine Ridge West Repeater Station lies along the crest of Pine Ridge, the amount of surface water infiltration is minor. The water table is estimated to be 180 to $230 \mathrm{ft}$ below the former UST 2310-U site which, when coupled with the low-to-medium infiltration rates, suggests a low probability that free product migrated to the water table. There was no evidence of vegetative stress along the hillside and no standing free product was observed in the excavated pit. Consequently, a free-product recovery investigation at the site was not conducted. Further details regarding the decision not to initiate a free-product recovery investigation are presented in the Initial Abatement Report, included in Appendix B of the EAR/CAP for the site.

\subsection{SITE INVESTIGATION}

Field work for the Site Investigation was conducted in July 1990. During this investigation, three soil borings (locations 6, 7, and 8 on Figure 2.1) were drilled to delineate the horizontal extent of contamination. The locations of these borings were based on anticipated preferential flow directions, downslope to the north and south of the tank. Boring 6 was located north of the UST 2310-U pit and was advanced to refusal of the sampling device at a depth of $5.4 \mathrm{ft}$ below ground surface (BGS). Boring 7 was located southwest of the tank pit and was advanced to refusal at $8.0 \mathrm{ft}$ BGS. Boring 8 was located southeast of the tank pit and was advanced to a depth of $20.8 \mathrm{ft}$ BGS. A single sample at a depth of $\sim 5 \mathrm{ft}$ BGS was collected from borings 6 and 7 . Samples were taken at 5 -ft intervals in boring 8 .

Soil samples collected for the Site Investigation were analyzed for benzene, toluene, ethylbenzene, and xylenes (BTEX), TPH, and lead. A summary of the analytical methods and results is provided in Table 2.2. The laboratory analytical results for these samples are presented in Appendix F of the EAR/CAP for the site. These analytical results indicated that all of the Site Investigation soil samples contained nondetectable levels of total BTEX. TPH levels for all samples were found to be below the most stringent TDEC Closure Action Level $(<100 \mathrm{ppm})$. Lead levels for the soil samples were within a general range documented within the Y-12 Plant area.

\subsection{INITIAL VERTICAL CONTAMINATION EXTENT SAMPLING}

Based on the results of the ISC and Site Investigation phases of the Environmental Assessment, additional soil sampling activities were necessury to determine the vertical extent of petroleum contamination. Therefore, on February 19 and 20, 1992, four additional boreholes were drilled at the site, three for the purpose of soil sample collection for laboratory analysis and one for the collection of a Shelby Tube sample for permeability analysis.

Two of the three boreholes (BH-1 and $\mathrm{BH}-3$ ) designated for soil sample collection were drilled immediately north of the former UST 231()-U pit, to depths of 16 and $17 \mathrm{ft} \mathrm{BGS,} \mathrm{at} \mathrm{which} \mathrm{point}$ competent bedrock was encountered. The third borehole (BH-2) was drilled within the former tank pit, near the north side of the pit, to a depth of $9 \mathrm{ft}$ BGS. The fourth borehole (S-1) designated for Shelby Tube sampling was drilled immediately adjacent to BH-3 to a depth of $14 \mathrm{ft}$ BGS. The locations of boreholes drilled during this investigation are presented in Figure 2.1.

Soil samples were collected continuously at 2.5-ft intervals, using 5-ft split spoons, over the entire depth of BH-1 and BH-3 for the purpose of field screening. None of the sampled intervals from these two boreholes was found to exhibit petroleum contamination as determined by the field screening. Therefore, three soil sample intervals from each borehole were selected for laboratory analysis as follows: (BH-1) 5.0-7.5 ft, 10.0)-12.5 ft, and 15.0-16.0 ft; (BH-3) 5.0-7.5 ft, 12.5- 
$15.0 \mathrm{ft}$, and 16.0-17.0 ft. One soil sample was collected hetween 6.0 and 7.() ft BGS from borehole BH-2. The Shelby Tube soil sample from borehole $S-1$ was collected between 7.0 and $9.5 \mathrm{ft}$ BGS.

Samples collected from boreholes BH-1 and BH-3 were analyzed for BTEX constituents, TPH, and total lead. The single sample collected from borehole BH-2 only underwent analysis for TPH since the soil in the former tank pit had previously been characterized for BTX during the tank removal. Analytical results for these samples are summarized in Table 2.2. The laboratory analytical results are presented in Appendix $\mathrm{H}$ of the EAR/CAP for the site.

Results for all samples collected from boreholes $\mathrm{BH}-1$ and $\mathrm{BH}-3$ indicated the nondetectable levels of total BTEX, and TPH levels below the most stringent TDEC Closure Action Level $(<100 \mathrm{ppm})$. Lead levels for these samples were within a general range documented within the Y-12 Plant area. The level of TPH detected in borehole BH-2 was $3400 \mathrm{ppm}$. This finding, along with the results from the previous site investigations, indicated that the extent of petroleum contamination at the site was limited to the area of the former tank pit. Physical testing of the Shelby Tube sample from borehole S-1 indicated that the hydraulic conductivity of soil at the Pine Ridge West Repeater Station is $1.7 \times 10^{-5}$. The analytical method and the result for the Shelby Tube sample are presented in Appendix I of the EAR/CAP for the site.

\subsection{ADDITIONAL VERTICAL CONTAMINATION EXTENT SAMPLING}

At the request of TDEC, additional soil sampling at the Pine Ridge West Repeater Station was conducted to provide further analytical data for the interval between $7 \mathrm{ft}$ BGS and bedrock (or refusal) below the former tank pit. On Octoher 14, 1993, one soil boring (SB-4) located at the approximate center of the former tank pit (Figure 2.1) was drilled to auger refusal at 19.3 ft BGS.

Soil samples were collected at 2.5 -ft intervals using a 5 -ft split-spoon sampler beginning at a depth of $7 \mathrm{ft} \mathrm{BGS} \mathrm{(the} \mathrm{base} \mathrm{of} \mathrm{the} \mathrm{tank} \mathrm{pit).} \mathrm{Samples} \mathrm{were} \mathrm{collected} \mathrm{at} \mathrm{intervals} \mathrm{of} \mathrm{7.0-9.5} \mathrm{ft,} \mathrm{9.5-}$ $12.0 \mathrm{ft}, 12.0-17.0 \mathrm{ft}$, and 17.()-19.3 ft BGS, and sent for laboratory analysis for BTEX constituents, Total Petroleum Hydrocarbons-Gasoline Range Organics (TPH-GRO), and lead.

The results of this sampling are summarized in Table 2.2. The results indicate that contamination in the sampled intervals is well below the most stringent TDEC Closure Action Levels. A letter report including field notes from the sampling event, the summarized analytical data, and the original laboratory analytical sheets was submitted to TDEC (letter from Robert Spence to Earl C. Leming, dated November 17, 1993; see letter without enclosures in Appendix A of this document). Based on this report, TDEC concluded that contamination has neither migrated to bedrock nor potentially impacted groundwater. TDEC further noted that no further investigation to delineate the extent of groundwater contamination was required at the site (letter from James Harless to Robert Spence, dated December 6, 1993; see Appendix B of this document). Implementation of soil corrective action in accordance with the EAR/CAP was hegun following this notification.

\subsection{EVALUATION OF DATA FROM PREVIOUS INVESTIGATIONS}

Based on soil permeability data collected during the Initial Vertical Contamination Extent study and the classification of the site as a nondrinking water standard setting (as justified in the approved EAR/CAP for the site) the applicable TDEC Closure Action Levels for soil at the site are $500 \mathrm{ppm}$ TPH and $250 \mathrm{ppm}$ BTEX. As discussed in Section 1.1, groundwater is not a medium of concern for the site. 
The analytical results from previous investigations conducted at the site have shown that soil contamination above the applicable TDEC Closure Action Levels is limited to the area within and directly helow the original tank pit. 


\subsection{SOIL CORRECTIVE ACTION PROGRESS AND PROBLEMS}

Corrective action proposed for the UST 2310-U site included overexcavation of contaminated soil aided by field soil screening, confirmatory soil sampling of the excavation, and proper disposal of the contaminated soil. Initial corrective action activities began on April 8, 1994. However, two of five confirmatory samples collected from the periphery of the excavation indicated the continued presence of soil in excess of applicable action levels at the site. Therefore, an additional excavation and sampling event was conducted to remove the remaining contaminated soil above the specified TDEC Action Limit at the site. The following sections provide a description of corrective action and soil sampling activities, and report the results of confirmatory soil sampling for the two rounds of excavation and sampling. Field notes for the initial excavation and confirmatory soil sampling are provided in Appendix C. Appendix D provides field notes for the final round of excavation and sampling.

\subsection{INITIAL CORRECTIVE ACTION ACTIVITIES}

\subsubsection{Initial Excavation}

Corrective action began by excavaling soil in the original tank pit using a backhoe. During excavation, soil removed from the pit was placed in a dump truck and taken to the Pumphouse Area at the western area of the Y-12 Plant for temporary storage. After initially excavating the pit to a dimension of $10 \mathrm{ft} \times 8 \mathrm{ft} \times 6 \mathrm{ft}$ deep, an organic vapor meter (OVM) and a field gas chromatograph $(\mathrm{GC})$ were used to screen samples to guide further excavation. After widening the pit and excavating to a depth of $11 \mathrm{ft}$ BGS in the southwest corner of the pit the decision was made to perform confirmatory sampling. This decision was based on the proximity of the excavated pit to the Repeater Station building and to time constraints in restoring power to the repeater facility. During this excavation event $\sim 41 \mathrm{yd}^{3}$ of soil were removed from the site. Following confirmatory sampling the excavation pit was filled with clean clay.

\subsubsection{Initial Confirmatory Sampling}

Following the completion of excavation, one confirmatory soil sample was collected from each of the four corners of the pit and two samples (one, a duplicate) were collected from the approximate center of the pit (Figure 3.1). Samples were collected from the base of the excavation using a backhoe at an approximate depth of 10 to $11 \mathrm{ft}$ BGS. Samples were taken from the backhoe bucket in accordance with Method ESP-3(1)3-1. Soil Sampling Using a Spade and Scoop. Sample container, preservation, packaging, shipping. and recommended holding times followed guidelines in Method ESP-7()1, Sampling Preservation and Container Materials. Decontamination followed procedures outlined in Method ESP-801. Equipment Decontaminarionn. Confïrmatory samples were analyzed for BTEX constituents and TPH-GR().

\subsubsection{Results of Initial Confirmatory Sampling}

Analytical methods and results for the confirmatory samples are presented in Table 3.1. Original laboratory data sheets are presented in Appendix E. These results indicated that soil contamination above the applicable TDEC Closure Action Levels (50) $\mathrm{ppm}$ TPH-GRO and 250 ppm BTEX) remained at the site. Levels of TPH-GRO of $13(\%) \mathrm{ppm}$ and total BTEX of $36(0.7 \mathrm{ppm}$ were found in the soil sample collected from the northeast corner of the pit. Levels of TPH-GRO of $1600 \mathrm{ppm}$ and total BTEX of $695 \mathrm{ppm}$ were found in the soil sample collected from the southwest corner of the pit. Samples collected from the center of the pit and from the northwest and southeast corners of the pit contained contaminant levels helow the most stringent TDEC Closure Action Levels. 


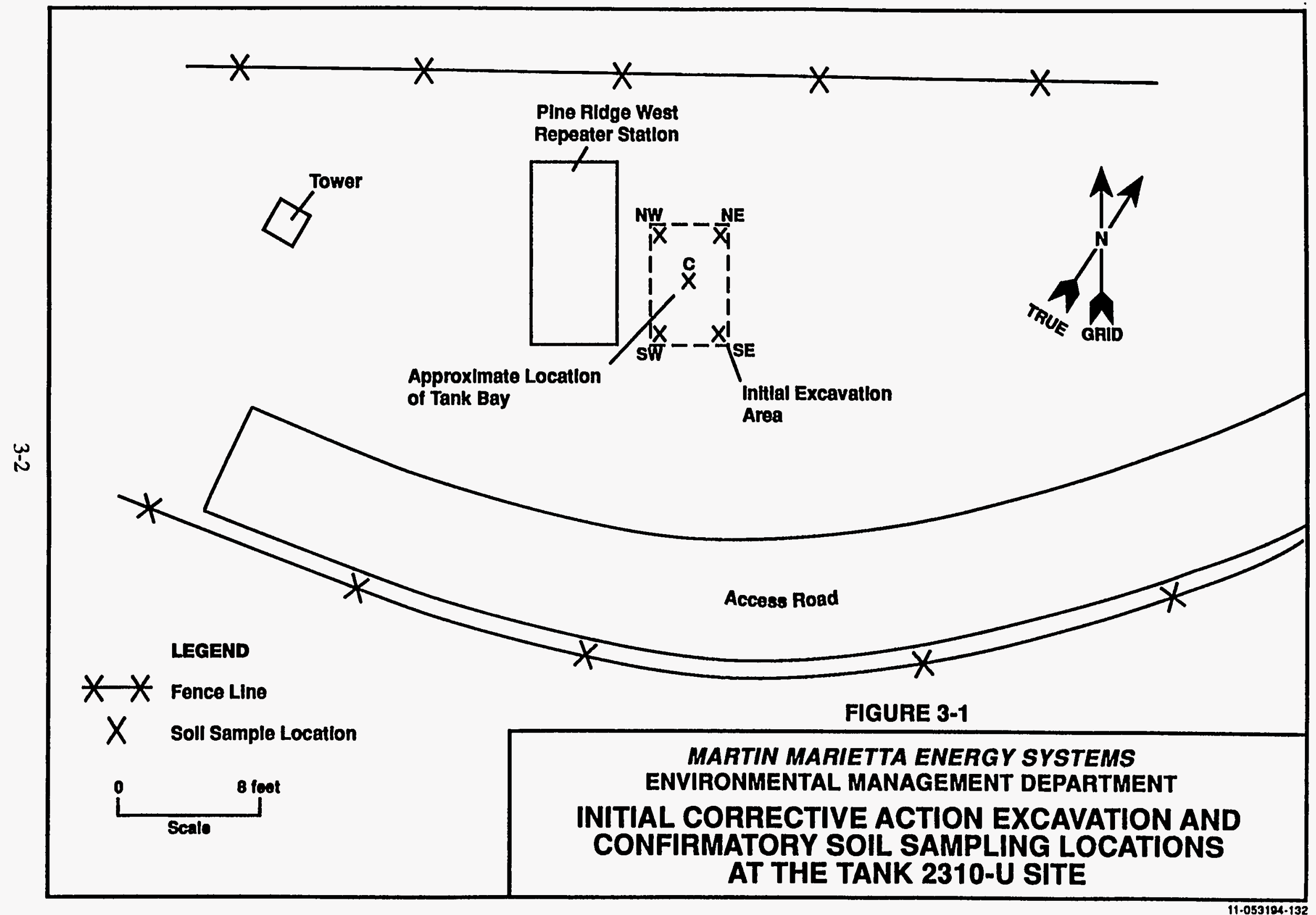


Table 3.1. Analytical results for confirmatory soil samples collected during initial corrective action excavation activities at the Tank 2310-U site, April 8, 1994

\begin{tabular}{|c|c|c|c|c|c|c|}
\hline $\begin{array}{r}\text { Contaminant: } \\
\text { Method: } \\
\text { Units: }\end{array}$ & $\begin{array}{c}\text { Benzene } \\
\text { SW846 } 8020 \\
\text { ppm }\end{array}$ & $\begin{array}{c}\text { Ethylbenzene } \\
\text { SW846 } 8020 \\
\text { ppm }\end{array}$ & $\begin{array}{c}\text { Toluene } \\
\text { SW846 } 8020 \\
\text { ppm }\end{array}$ & $\begin{array}{c}\text { Xylenes } \\
\text { SW846 } 8020 \\
\text { ppm }\end{array}$ & $\begin{array}{c}\text { TPH-GRO' } \\
\text { SW846 } 8020 \\
\text { ppm }\end{array}$ & $\begin{array}{c}\text { Total } \\
\sum \text { BTEX } \\
\text { ppm }\end{array}$ \\
\hline Sample Location & & & & & & \\
\hline Northeast corner & 6.7 & 53 & 91 & 210 & $1300 *$ & $360.7 *$ \\
\hline Southwest corner & 25 & 80 & 200 & 390 & $1600^{*}$ & $695.0 *$ \\
\hline Northwest corner & 0.032 & 0.085 & 0.440 & 0.590 & 2.4 & 0.751 \\
\hline Southeast corner & $0.020 U$ & 0.028 & 0.040 & 0.220 & 0.970 & 0.298 \\
\hline Center A & 0.042 & 0.085 & 0.370 & 0.460 & 2.100 & 0.957 \\
\hline Center B & $0.002 \mathrm{~J}$ & 0.069 & 0.100 & 0.500 & 1.400 & 0.6710 \\
\hline
\end{tabular}

'Total Petroleum Hydrocarbons-Gasoline Range Organics.

*Indicates contaminant level greater than the most stringent TDEC Closure Action Level for soil.

J-Estimated value.

U-Contaminant not detected during the analysis. 
Based on these results it was evident that additional excavation and confirmatory sampling was required in the northeast and southwest portions of the pit.

\subsection{SECOND EXCAVATION AND CONFIRMATORY SAMPLING}

Additional excavation and confirmatory soil sampling was conducted on May 5, 1994. During this event, excavation began by removing the clean fill placed in the southwest comer of the pit during the previous excavation. Soil in the southwest comer was excavated to a depth of $11 \mathrm{ft}$ BGS. Guided by field screening (OVM and field GC) additional soil was removed beyond the extent of the first excavation. Based on the results of field screening, which indicated that the limit of contaminated soil had been reached in the southwest corner, a confirmatory sample was collected at a depth of $\sim 9 \mathrm{ft} \mathrm{BGS}$, at a location $\sim 7 \mathrm{ft}$ southeast of the corner of the Pine Ridge West Repeater Station.

Clean fill in the northeast corner of the original excavation was pushed toward the southwest portion of the pit. Remaining clean fill and potentially contaminated native soils were removed and placed in a dump truck. After excavating to a depth of $11.4 \mathrm{ft}$ BGS in the northeast comer of the pit, field GC screening results indicated that the limit of contaminated soil had been reached. At this point a second confirmatory soil sample was collected. The extent of the second excavation and the locations of samples collected during this event are presented in Figure 3.2.

During this second excavation event, $\sim 18 \mathrm{yd}^{3}$ of soil were removed from the former UST 2310-U pit location. Excavated soils were taken to the Pumphouse Area at the western area and staged with soils from the initial excavation. Soils were enclosed in plastic awaiting proper characterization, treatment, and disposal. Soil sampling and associated activities conducted during the second excavation followed the same procedures and practices as the first excavation event. The additional confirmatory samples were analyzed for BTEX constituents and TPH-GRO.

\subsubsection{Final Sampling Results}

Analytical methods and results for the confirmatory samples collected for the second excavation activity are presented in Table 3.2. Original lahoratory data sheets are presented in Appendix F. Results for these samples indicate BTEX constituents were not detected, and TPH-GRO concentrations were $<1(10) \mathrm{ppm}$. These results are helow the most stringent TDEC Closure Action Levels for soil. 


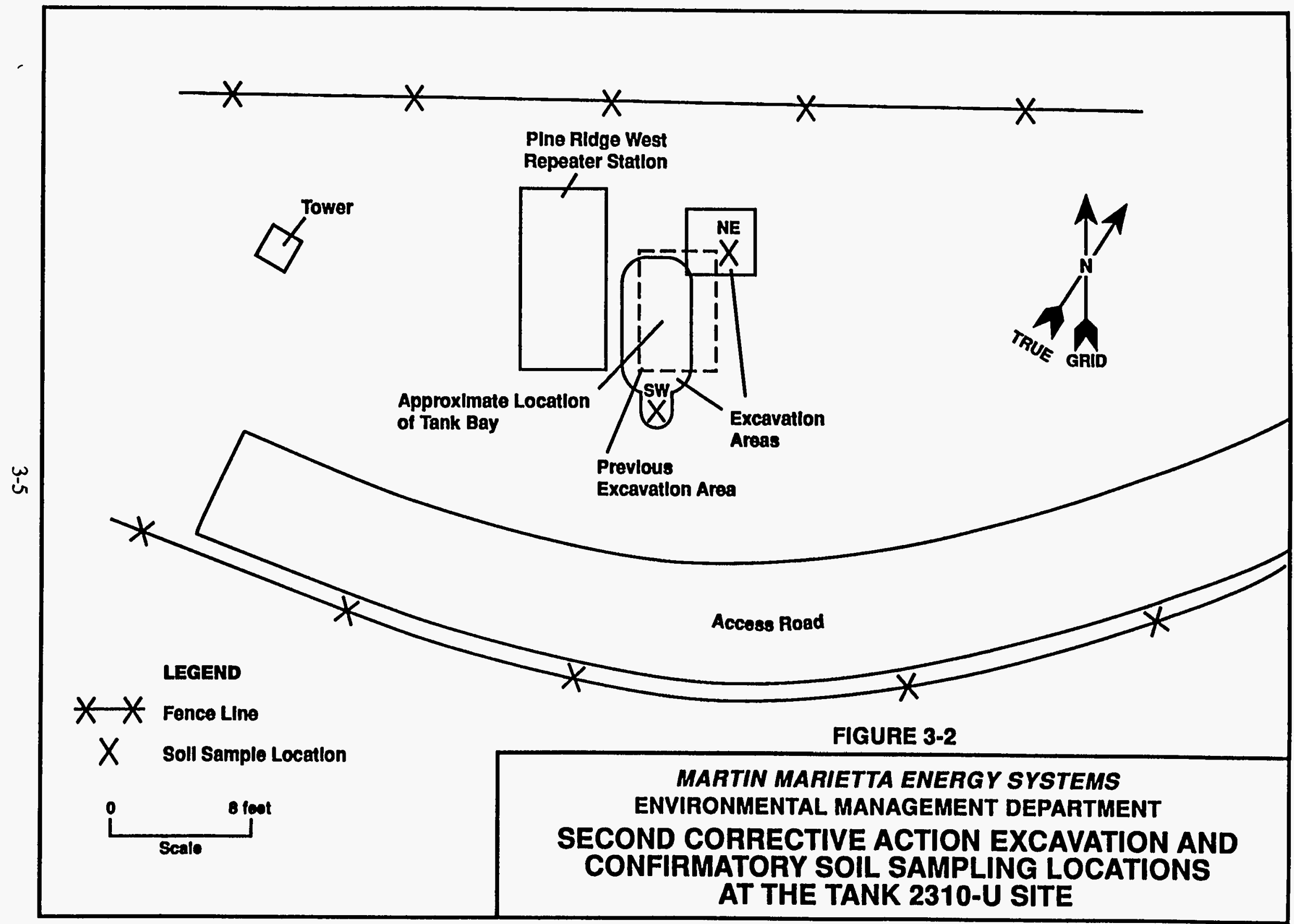


Table 3.2. Analytical results for confirmatory soil samples collected during additional corrective action excavation activities at the Tank 2310-U site, May 5, 1994

\begin{tabular}{|c|c|c|c|c|c|c|}
\hline $\begin{array}{r}\text { Contaminant: } \\
\text { Method: } \\
\text { Units: } \\
\end{array}$ & $\begin{array}{c}\text { Benzene } \\
\text { SW846 } 8020 \\
\text { ppm }\end{array}$ & $\begin{array}{c}\text { Ethylbenzene } \\
\text { SW846 } 8020 \\
\text { ppm } \\
\end{array}$ & $\begin{array}{c}\text { Toluene } \\
\text { SW846 } 8020 \\
\text { ppm } \\
\end{array}$ & $\begin{array}{c}\text { Xylenes } \\
\text { Sw846 } 8020 \\
\text { ppm } \\
\end{array}$ & $\begin{array}{c}\text { TPH-GRO } \\
\text { SW846 } 8020 \\
\text { ppm } \\
\end{array}$ & $\begin{array}{c}\text { Total } \sum \text { BTEX } \\
\text { SW846 } 8020 \\
\text { ppm }\end{array}$ \\
\hline $\begin{array}{l}\text { Sample Location } \\
\text { Northeast corner } \\
\text { Southwest corner }\end{array}$ & $\begin{array}{l}.010 U \\
.010 U\end{array}$ & $\begin{array}{l}.010 U \\
.010 U\end{array}$ & $\begin{array}{l}.010 U \\
.010 U\end{array}$ & $\begin{array}{l}.010 U \\
.010 U\end{array}$ & $\begin{array}{l}.100 \mathrm{U} \\
.002 \mathrm{BJ}\end{array}$ & $\begin{array}{l}\mathrm{ND}^{2,3} \\
\mathrm{ND}^{2,3}\end{array}$ \\
\hline
\end{tabular}

${ }_{1}^{1}$ Total Petroleum Hydrocarbons-Gasoline Range Organics.

${ }^{2}$ Sum of benzene, toluene, ethylbenzene, and xylene.

${ }^{3} \mathrm{ND}$ - All components of the BTEX summation were below detection.

B-Contaminant found in the associated blank.

J-Estimated value.

U-Contaminant not detected during the analysis. 


\subsection{SUMMARY AND CONCLUSIONS}

Based on analytical data from soil samples collected at the site during the ISC, the Site Investigation, and the two studies conducted at the site to determine the vertical extent of contamination, petroleum contamination was found to be limited to soils within and directly below the original tank pit. Based on the estimate that the water table at the Pine Ridge West Repeater Station is 180 to $230 \mathrm{ft}$ BGS, combined with analytical data that have shown that petroleum contamination has not migrated to bedrock and potentially affected groundwater, groundwater was not a medium of concern.

Corrective actions implemented at the site included two rounds of excavation resulting in the removal of $\sim 59 \mathrm{yd}^{3}$ of soil from the UST 2310 -U pit and adjacent areas. Petroleum-contaminated soils removed during both rounds of excavation were staged at the Pumphouse Area at the west end of the Y-12 Plant and enclosed in plastic. These soils will be properly characterized, treated, and/or disposed of in accordance with the applicable TDEC guidance. Pending completion of these activities, TDEC will be notified of the disposition of the waste soil.

Confirmatory sampling conducted following the excavation activities has provided analytical results that indicate that the limit of BTEX and TPH-GRO contamination above the most stringent TDEC Closure Action Levels has been defined. Petroleum-contaminated soils potentially above this level have been removed from the site, and the excavation has been backfilled with clean clay. Therefore, in accordance with TDEC Rule 12(1)-1-15-.(16, closure of the UST 2310-U site is requested. 


\subsection{REFERENCES}

Energy Systems (Martin Marietta Energy Systems, Inc.), 1993. Environmental Assessment and Corrective Action Plan for Underground Storage Tank 2310-U, Pine Ridge West Repeater Station, Y/SUB/93-99928C/Y20/2, Oak Ridge Y-12 Plant, Oak Ridge, TN.

EPA (U.S. Environmental Protection Agency), March 1985. Methods for Chemical Analysis of Water and Wastes, EPA-600/4-79-020.

EPA, November 1986. Test Methods for Evaluating Solid Waste Physical/Chemical Methods, SW-846, 3rd Edition.

Geraghty and Miller, Inc., October 1986. Aquifer-Test Data and Design of Recovery Wells; S-3 Ponds, Prepared for Martin Marietta Energy Systems, Inc., Y/SUB/86-00206C/2.

King, H.L., and C.S. Haase, April 1987. Subsurface-Controlled Geologic Map for the Y-12 Plant and Adjacent Areas of Bear Creek Valley, ORNL/TM-10112.

Moneymaker, R.H., 1981. Soils Survey of Anderson County, Tennessee, U.S. Department of Agriculture, Soil Conservation Survey, Washington, D.C.

Rothschild, E.R., R.R. Turner, S.H. Stow, M.A. Boyle, L.K. Hyder, O.M. Sealand, and H.J. Wyrick, November 1984. Investigation of Subsurface Mercury at the Oak Ridge Y-12 Plant, ORNL/TM-9092. 


\section{APPENDIX A}

\section{LETTER FROM R.J. SPENCE TO E.C. LEMING}




\section{Department of Energy}

Oak Ridge Operations Office

P.O. Box 2001

Oak Ridge. Tennessee $37831-8555$

November 17, 1993

Mr. Earl C. Leming

Tennessee Department of Environment

and Conservation

DOE Oversight Division

761 Emory Valley Drive

Oak Ridge, Tennessee 37930-7072

Dear Mr. Leming:

VERTICAL DELINEATION OF PETROLEUM CONTAMINATION AT THE PINE RIDGE WEST UNDERGROUND STORAGE TANK (UST) SITE, Y-12 PLANT

On October 5, 1993, Jim Harless of your staff requested additional information pertinent to the vertical delineation of petroleum contamination at the Pine Ridge West UST site. Additional sample data was requested for the interval seven feet to bedrock (refusal).

On October 14, 1993, four split-spoon samples were taken from the target interval starting at seven feet and continuing until refusal at 19.3 feet. The samples retrieved were analyzed for (1) lead; (2) benzene, toluene, ethyl benzene and xylenes (BTEX); and (3) total petroleum hydrocarbon-gasoline range organics (TPH-GRO). A compilation of the available results is provided below.

\begin{tabular}{|c|c|c|c|}
\hline SAMPLE INTERVAL & LEAD (ppm) & BTEX (ppm) & TPH-GRO (ppm) \\
\hline $7 \mathrm{ft}-9.5 \mathrm{ft}$ & 22 & $<0.020$ & $<0.5$ \\
\hline $9.5 \mathrm{ft}-12.0 \mathrm{ft}$ & 10 & $<0.020$ & $<0.5$ \\
\hline $12.0 \mathrm{ft}-17.0 \mathrm{ft}$ & 62 & $<1.25$ & 24 \\
\hline $17.0 \mathrm{ft}-19.3 \mathrm{ft}$ & 1.1 & $<0.0205$ & $<0.5$ \\
\hline
\end{tabular}

These results establish the vertical extent of petroleum contamination below the former tank pit and reinforce the overexcavation of contamination that is present at this UST site. The field notes from the sampling activity are provided as Enclosure 1. The hard copy of the analytical results are provided as Enclosure 2. 
Mr. Earl C. Leming

If you have any questions concerning this information, please contact Bill McMillan of my staff at $576-2409$.

DP-813:McMillan

Sincerely,

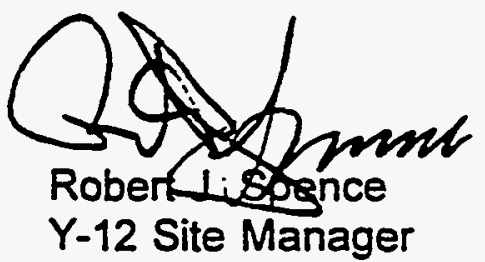

\section{Enclosures}

cc w/enclosures:

P. Chambers, TDEC, Knoxville

C. Head, TDEC, Nashville

P. J. Gross, SE-31, ORO

J. E. Powell, 9116, MS 8098, Y-12

S. W. Wiley, 9709 , MS 8226, $Y-12$

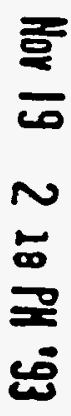




\section{APPENDIX B}

LETTER FROM J. HARLESS TO R.J. SPENCE 


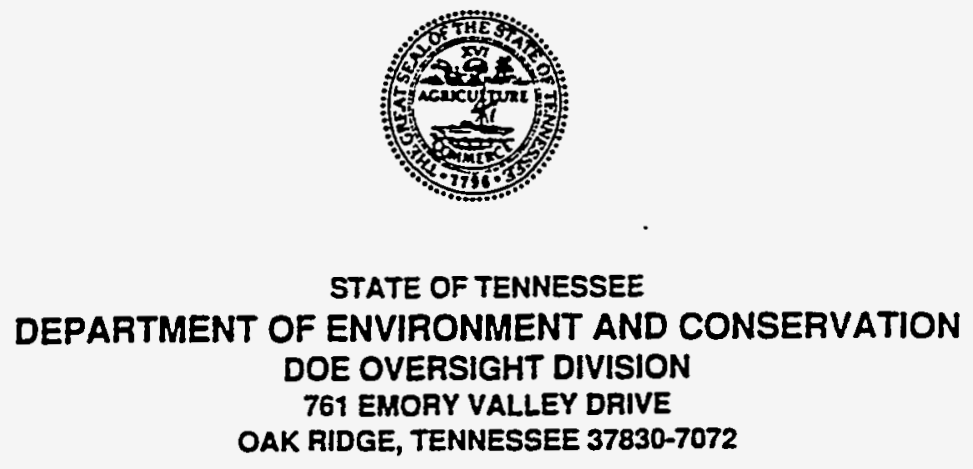

December 6, 1993

Mr. Robert J. Spence

U.S. Department of Energy

P.O. Box 2001

Oak Ridge, TN 37831

Dear Mr. Spence

RE: Vertical Extent of Petroleum Contamination

Pine Ridge West Underground Storage Tank (UST) Site

Y-12 Plant, Oak Ridge, Tennessee

Facility ID \#0-010117, Roane county

Reference 1. Letter, Robert Spence to Earl C. Leming, Subject Vertical Delineation of Petroleum Contamination at the Pine Ridge West UST Site, Y-12 Plant, November 17,1993

The Tennessee Department of Environment and Conservation, DOE oversight Division (TDEC/DOE-O) has received the November 17, 1993 report on soil sampling at the Pine Ridge West UST Site (Reference 1). In this report, four soil samples were taken in the former tank pit from seven to nineteen feet. These samples were taken to delineate the vertical extent of petroleum contamination and determine if petroleum contamination has reached bedrock. Analytical results from these samples indicate that petroleum contamination in this interval is well below the state's most stringent action limit.

Based upon these results, petroleum contamination has not migrated to bedrock and potentially impacted groundwater at this site. Investigations to delineate the horizontal and vertical extent of groundwater contamination will not be required at this site. 
MI. Robert Spence

December 6, 1993

Page Two

If you have any questions, please contact Jack wheat at (615) 4810995.

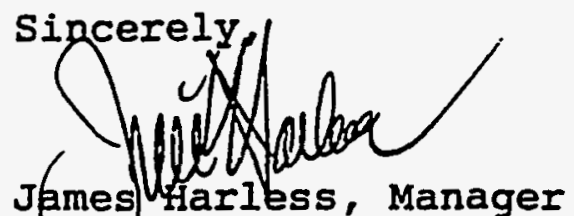

carretive Action and Compliance Section

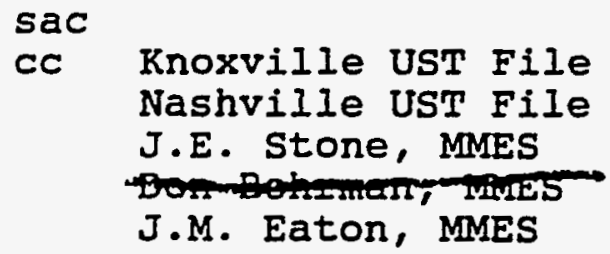

ca0379.01 
APPENDIX C

INITIAL EXCAVATION NOTES 


\section{PINE RIDGE WEST REPEATER STATION SOIL CORRECTIVE ACTION - OVEREXCAVATION FIELD NOTES: APRIL 8 AND 14, 1994}

Summary: During this period of excavation and sampling, $\sim 41 \mathrm{yd}^{3}$ of soil were removed, and 5 environmental samples were collected. Excavation was directed by field screening using a field Gas Chromatograph (GC). Confirmatory samples were taken in the four corners of the excavation, and one was taken from the center of the excavation. These samples were submitted for analysis of Total Petroleum Hydrocarbons - Gasoline Range Organics (TPH-GRO) and benzene, toluene, ethylbenzene, and xylene(s) (BTEX). The excavated soil was taken to the 0910 Pumphouse Area at the west end of the Y-12 Plant and enclosed in plastic. The excavation was back-filled with clean clay.

Personnel: $\quad$ Y-12

- Ed Ingram (UST Field Coordinator)

- Skip Brinkman (MMES Maintenance Supervisor)

- Jerry Lawless (Equipment Operator)

- Steve Nelson (Heavy Truck Driver)

- Jay Thomas (Labor Crew)

- Rudy Weigel (Y-12 HAZWOPER Coordinator)

- Bill Sliski (Industrial Hygiene)

- Janet Sitzler (HSEA Sampler)

- Earl Broadway (HSEA Sampler)

$\mathrm{X}-10$

- Jim Wade (X-10 GC Soil Screening)

April 8, 1994

0800 Arrived at job site. Line Crew begin disconnecting electric power to Building 9724-3, Pine Ridge West Repeater Station. Emergency generator takes over load for Plant Radio System.

0915 Backhoe arrives at job site. Rudy Weigel gives HAZWOPER briefing and all personnel sign attendance sheet.

0930 Set up construction barrier around excavation site.

0940 Jim Wade, X-10 GC Field Screening, arrived and backhoe began excavation. No petroleum smell noticed at this stage of excavation.

0955 Excavation pit size $10 \mathrm{ft} \times 8 \mathrm{ft} \times 6 \mathrm{ft}$ deep. No petroleum smell noticed at this point. Soil of pit appeared to be within the plastic liner left when the tank was removed.

1010 Dump truck departed, estimated load at $13 \mathrm{yd}^{3}$. Rudy Weigel brought up soil from bottom of pit and checked with OVM instrument - maximum reading of $177 \mathrm{ppm}$.

1030 Dump truck arrived back at job site and excavation continued. At a depth of $8 \mathrm{ft}$ the bottom of pit looked like native soil had been reached (shale residuum). 
1045 Jim Wade took a screening sample from the NW corner of pit using backhoe bucket to retrieve sample. All personnel departed site except Jim Wade.

1220 Arrived at job site. GC Soil Screening result from the NW corner was $30 \mathrm{ppm}$ toluene.

1230 Squaring-up sides of excavation pit to begin confirmatory sampling. Jim Wade takes another screening sample from the NW corner. OVM instrument reading of $18.5 \mathrm{ppm}$.

1245 HSEA samplers arrive. Results of screening sample shows toluene level to be off scale at $1500 \mathrm{ppm}$. Repositioned backhoe bucket to widen excavation to dig closure to repeater station. Backhoe had to dig cautiously because of building grounding cable 2-3 ft west of building. Dump truck departed, estimated load to be $10 \mathrm{yd}^{3}$.

1310 Soil screening sample taken from SW corner of excavation pit. Results show the toluene level to be $300 \mathrm{ppm}$.

1320 Resume excavating near repeater building, noticed native soil at $18 \mathrm{in}$. from building. No digging any closure to the building to avoid undermining foundation. Plastic liner was removed.

1330 Another soil screening sample taken from SW corner of pit floor at a depth of $10 \mathrm{ft}$. Resuits indicate toluene level to be $1,113 \mathrm{ppm}$. A slight petroleum odor was noticed coming from excavation pit.

1350 Dump truck departed, estimated load at $12 \mathrm{yd}^{3}$.

1410 Dump truck arrived at a job site with $12 \mathrm{yd}^{3}$ of clean clay, dumped near building and repositioned truck for loading.

1415 Squaring-up excavation pit, depth of pit measures $\sim 11 \mathrm{ft}$ in $\mathrm{SW}$ corner. Due to both time constraints in restoring power and limited excavation space the decision was made to proceed with confirmatory sampling.

1420 Sample taken from NW (E940980176) corner of excavation pit.

1425 Sampled SW (E940980182) corner at a depth of 10-11 ft. OVM reads $722 \mathrm{ppm}$. A slight petroleum odor was present near SW corner.

1429 Sampled SE (E940980183) corner at a depth of $10 \mathrm{ft}$. OVM reads $612 \mathrm{ppm}$.

1430 Sampled Center (E940980184 \& E940980185) locations (duplicate) on pit floor. A duplicate sample was taken at this location. OVM reads $174 \mathrm{ppm}$.

1435 Sampled NE (E940980186) comer. OVM reads $621 \mathrm{ppm}$. All samples properly packaged for shipment under chain-of-custody No. 20406. A slight petroleum smell was noticed. Dump truck departed from site, estimated load at $6 \mathrm{yd}^{3}$. 
1440 Line crew arrived and restored power to repeater station. Backhoe operator pushed clean clay into excavation pit. Departed to PPS Office and signed-off Line Tag-Out Order. Enclosed spoil pile at the 0910 Pumphouse site.

1515 Arrived back at job site, locked gate to repeater station.

1545 Informed PSS of condition of job site (open hole situation).

April 14. 1994

$1200-1500$

Maintenance delivered clean clay to site and closed excavation pit. 
APPENDIX D

SECOND EXCAVATION NOTES 


\section{TANK PIT OVER-EXCAVATION AND SOIL SAMPLING AT PINE RIDGE WEST REPEATER STATION (TANK 2310-U), OVERSIGHT FIELD NOTES, MAY 5, 1994}

\section{Summary:}

During this period of excavation and sampling, $-18 \mathrm{yd}^{3}$ of soil were removed. The southwest and northeast corners of the previous tank pit excavation were over-excavated in response to sampling results. Grab samples were collected from the floor of the excavation and submitted for analysis of Total Petroleum Hydrocarbons-Gasoline Range Organics (TPH-GRO) compounds and benzene, toluene, ethyl benzene, and total xylene (BTEX). The excavated area was backfilled with clean soil taken from the Y-12 Landfill V area. The excavated materials were taken to the 0910 pumphouse area at the western end of the Y-12 Plant to be encapsulated with plastic awaiting proper characterization, treatment, and disposal.

Personnel:

$\begin{array}{ll}\text { Y-12 } & \text { D. Bohrman (UST Program Manager) } \\ & \text { E. Ingram (UST Program Field Coordinator) } \\ & \text { R. Weigel (Hazwoper Health and Safety Officer) } \\ & \text { E.T. Brinkman (Maintenance Supervisor) } \\ & \text { B. Bryan, Jr. (Backhoe Operator) } \\ & \text { J.M. Hitch (Truck Driver) } \\ & \text { R.L. Anderson (Labor Crew) } \\ & \text { J. Stizler (HSEA Sampler) } \\ & \text { E. Broadway (HSEA Sampler) } \\ \text { X-10 } & \text { J. Wade (GC Operator) } \\ \text { TDEC } & \text { J. Wheat (UST DOE/O) } \\ \text { SAIC } & \text { S.L. Abston (Field Oversight) }\end{array}$

May 5, 1994

0800 Arrived at the Pine Ridge West Repeater Station, UST site. Weather conditions: $\sim 60^{\circ} \mathrm{F}$ sunny.

0810 E. Ingram and R. Weigel arrived at site; discussed and prepared excavation areas and reviewed appropriate documents and permits.

0817 E. Ingram departed site to talk with equipment operators.

0850 J. Wade arrived at site and began setting up GC equipment in the Repeater Station building. GC equipment calibrated to read benzene. E. Ingram returned to site.

0920 Backhoe and dump truck arrived at site (B. Bryan, Jr.; M. Hitch; R.L. Anderson). 
Pine Ridge West Repeater Station Tank 2310-U

Oversight Field Notes, May 5, 1994

Page 3 of 4

0930

E.T. Brinkman and D. Bohrman arrived on site.

0940 Health and safety meeting conducted by R. Weigel. An OVM Model 5800 ( $\$$ M-249366) was used to monitor site.

1000 Backhoe was electrically grounded and excavation begun in the southwest corner of the previous tank excavation. Removed the clean fill that had been placed in the previous tank excavation and loaded it into the dump truck. Fill was a reddish brown clay with some weathered, stained chert fragments.

1002 J. Wheat (TDEC) arrived on site.

1003 E.T. Brinkman departed site.

1005 E. Ingram departed site.

1025 Excavated to $11 \mathrm{ft}$ below ground surface (BGS) in SW corner. Hydrocarbon odor emanating from excavation. R. Weigel measured $33.1 \mathrm{ppm}$ in the excavation with 0.0-0.6 ppm in the breathing zone using the OVM. Black, weathered, stained shale at the bottom of the excavation. B. Bryan cleaned out excavation with the backhoe.

1028 Hydrocarbon odor from excavation had dissipated within 1 minute.

1031 E. Ingram arrived on site.

1035 Resumed excavating $\sim 1.5 \mathrm{ft}$ to the east of original excavation. Encountered very weathered shale at $\sim 4 \mathrm{ft}$ BGS.

1042 J. Wade collected a screening sample from the floor of the excavation with the backhoe bucket in the SW corner at $9 \mathrm{ft}$ BGS $(\sim 3 \mathrm{ft}$ west of the limit of the previous excavation). HNu reading was $50 \mathrm{ppm}$. Field $\mathrm{GC}$ reading of $2.75 \mathrm{ppm}$ benzene.

1046 Resumed excavating undisturbed soil to the west; weathered shale encountered within $1 \mathrm{ft}$ of the surface. D. Bohrman departed site.

1051 E.T. Brinkman arrived on site. R. Weigel discussed the need for a fan to dissipate intermittent hydrocarbon vapors.

$1055 \mathrm{~J}$. Wade collected a second screening sample from backhoe bucket in the SW corner at $10.5 \mathrm{ft}$ BGS and $4.5 \mathrm{ft}$ from the corner of the building. HNu reading was $45 \mathrm{ppm}$. Small pockets of soil appear to be the source of hydrocarbon odors.

1100 Broke for lunch. Transferred $\sim 10 \mathrm{yd}^{3}$ of soil to the 0910 Pumphouse Area at the western end of the Y-12 plant to be covered with plastic and stored pending disposal. 
Pine Ridge West Repeater Station Tank 2310-U

Oversight Field Notes, May 5, 1994

Page 4 of 4

1215 All personnel returned to site. J. Sitzler and E. Broadway (Y-12 HSEA Samplers on site).

1225 Resumed excavation of soils in the SW corner ( $\sim 7 \mathrm{ft}$ from the building). At $\sim 0.5 \mathrm{ft}$ BGS, a cold electrical wire was cut by the backhoe bucket.

1245 J. Wade collected a screening sample from the SW corner (from the backhoe bucket) at $\sim 9 \mathrm{ft}$ BGS and $7 \mathrm{ft}$ from the corner of the building (Figure 1). HNu reading was negative; field GC reading - $53.7 \mathrm{ppb}$ benzene. A fan was placed at the site to help dissipate the hydrocarbon odors. Stopped excavation to await GC results-excavated $\sim 4$ additional yds ${ }^{3}$ since lunch. Very resistant shale (bedrock) at $9 \mathrm{ft}$ BGS and not able to continue digging any deeper.

1300 GC results indicated that the limit of contaminated soil had been reached. Prepared to take a confirmatory sample with the backhoe bucket at the same depth as the screening sample.

1305 Samplers placed soil in a precleaned laboratory-grade $125 \mathrm{~mL}$ sample jar using a disposable Teflon ${ }^{\otimes}$ scoop. Samplers also placed soil into a $500 \mathrm{~mL}$ laboratory-grade sample jar provided by J. Wheat for the TDEC-DOE/O. Sample identified as SW sample.

1315 Prepared to excavate the NE corner of the original excavation pit. J. Wheat departed site to meet Health Physics personnel to scan the TDEC-DOE/O soil sample.

1320 Pushed clean fill toward the SW excavation.

1325 Loaded soil and weathered shale blocks into dump truck (clean fill mixed with native soils).

1348 Excavated to $11.4 \mathrm{ft}$ BGS and J. Wade took a sample from the backhoe bucket for screening with the GC. HNu reading was negative. Field GC reading - $45 \mathrm{ppb}$ benzene. Sample taken in native yellowish-brown clay with weathered to only slightly weathered shale and pockets of slightly weathered black shale (Figure 1). Removed $-4 \mathrm{yds}^{3}$ of soil.

1404 A second sample (same depth) was taken by J. Wade. Results showed HNu reading was negative. $\mathrm{GC}$ reading was $37 \mathrm{ppb}$ benzene.

1405 GC results indicated that the limit of contaminated soil had been reached. Samplers placed soil in a laboratory-grade $125 \mathrm{~mL}$ sample jar using a disposable Teflon ${ }^{\circledast}$ scoop. Sample identified as NE sample. Chain-of-custody number 20415 for both samples and two trip blanks. 


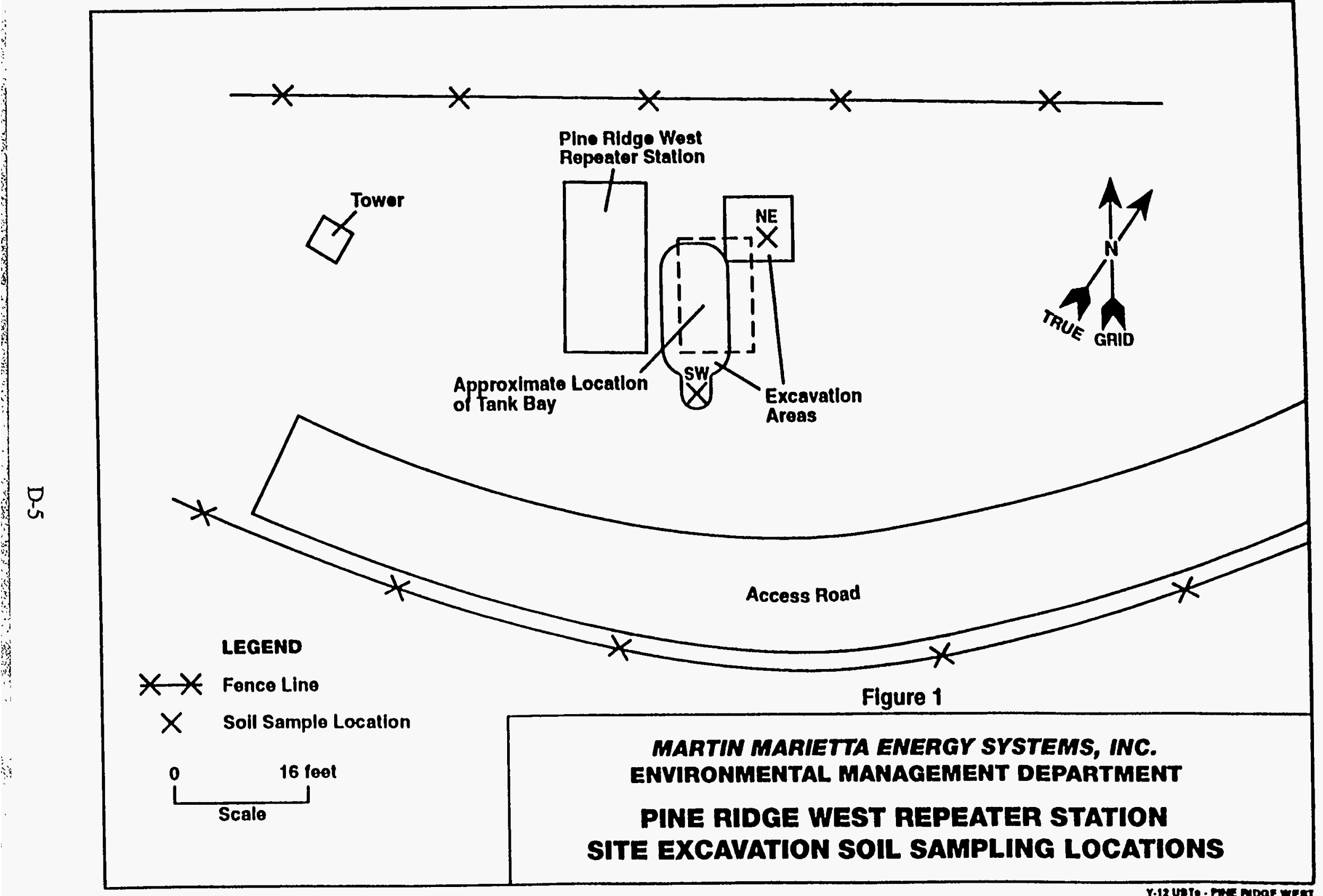


Pine Ridge West Repeater Station Tank 2310-U

Oversight Field Notes, May 5, 1994

Page 5 of 4

1412 Samplers departed site to deliver samples under custody to the Y-12 lab. Dump truck transferred $-8 \mathrm{yd}^{3}$ of soil to the 0910 pumphouse area at the western end of the $\mathrm{Y}-12$ Plant to be stored and covered with plastic.

1415 Backhoe departed site. Secured site for the day. Backfill with clean soil from Y-12's Landfill V scheduled for May 12, 1994.

\section{Sample and analytical summary:}

Two samples were collected from the excavation from the areas with elevated concentrations of TPH-GRO and BTEX during the original UST excavation. The locations of these sample points are shown on Figure 1. The sample from the SW corner of the excavated pit (ELIMS \#E941250039) was collected from a depth of $9 \mathrm{ft}$ BGS. The sample from the NE corner of the excavated pit (ELIMS \#E941250040) was collected from a depth of $11.4 \mathrm{ft} \mathrm{BGS.} \mathrm{A} \mathrm{trip} \mathrm{blank}$ consisting of two, $40-\mathrm{mL}$ VOA vials was used as a quality control measure (ELIMS \#E941250041). 
APPENDIX E

INITIAL CONFIRMATORY SAMPLING LAB DATA SHEETS 


\section{UNCLASSIFIED}

OFFICIAL REPORT

\section{SUBMITTER}

Ingram, Eduard Micha

ADDRESS

Building 9115 MS 8219

DATE SAMPLED: 04/08/94 14:20:00

DATE RECEIVED: 04/08/94

SAMPLER: 29776
DATE NEEDED: $04 / 22 / 94$

DATE COMPLETED: 04/22/94

SAMPLE DESCRIPTION: GRAB
CUSTOMER ID $\quad$ REQ HO $\frac{\text { SAMPLE HO }}{\text { E940980176 }}$

LOCATION: NORTH WEST SAMPLE

PROJECT CODE:
MTC STATUS

8403 APPROVED

CHARGE \#: S2205F21

CASE: U03163

COMMENTS: PINE RIDGE HEST REPEATER STATION

FINAL APPROVAL:

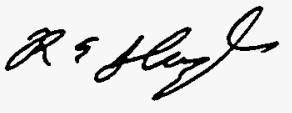

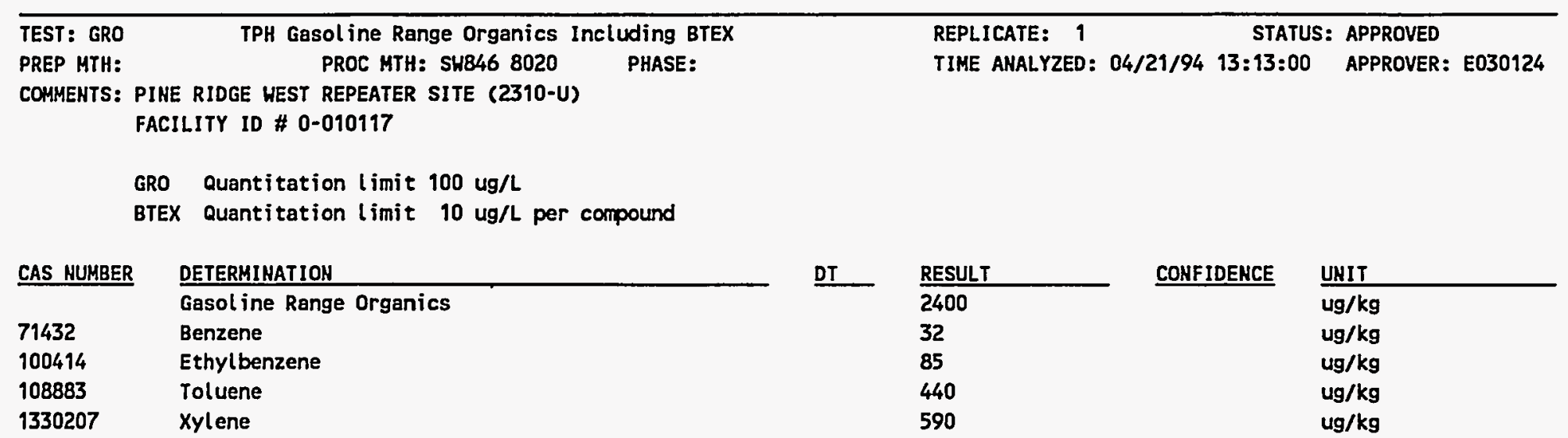




\section{UNCLASSIFIED}

OFFICIAL REPORT

05/26/94 13:18:01

Y-12 ANALYTICAL SERVICES ORGANIZATION

PAGE 1 OF 1

\section{SUBMITTER}

Ingram, Edward Hicha

DATE SAMPLED: 04/08/94 14:36:00

DATE RECEIVED: 04/08/94

SAMPLER: 029776

\section{ADDRESS}

Building 9115 HS 8219

DATE MEEDED : 04/22/94

DATE COMPLETED: $04 / 22 / 94$

SAMPLE DESCRIPTION: GRAB
CUSTOMER ID

LOCATION: NORTH EAST SAMPLE

PROJECT COOE:

FIHAL. APPROVAL: $\frac{\text { SAMPLE NO }}{\text { E940980186 }}$ 8403 APPROVED CHARGE \#: S2205F21 CASE: U03163

COMMENTS: PIME RIDGE HEST REPEATER STATION

TEST: GRO TPH Gasoline Range Organics Including BTEX

PREP MTH: COMMENTS

$$
\text { PROC MTH: SW846 } 8020 \text { PHASE: }
$$

PINE RIDGE HEST REPEATER SITE (2310-U)
FACILITY ID \# 0-010117

GRO Quantitation limit $100 \mathrm{ug} / \mathrm{L}$

BTEX Quantitation limit $10 \mathrm{ug} / \mathrm{L}$ per compound
REPLICATE: 1 STATUS: APPROVED

TIME ANALYZED: 04/21/94 19:06:00 APPROVER: E030124

\begin{tabular}{|c|c|c|c|c|c|}
\hline CAS NUMBER & DETERMINATION & DT & RESULT & CONFIDENCE & UNIT \\
\hline & Gasoline Range Organics & & 1300 & & $\mathrm{mg} / \mathrm{kg}$ \\
\hline 71432 & Benzene & & 6.7 & & $\mathrm{mg} / \mathrm{kg}$ \\
\hline 100414 & Ethylbenzene & & 53 & & $\mathrm{mg} / \mathrm{kg}$ \\
\hline 108883 & Toluene & & 91 & & $\mathrm{mg} / \mathrm{kg}$ \\
\hline 1330207 & Xylene & & 210 & & $\mathrm{mg} / \mathrm{kg}$ \\
\hline
\end{tabular}

UNCLASSIFIED 


\section{UNCLASSIFIED}

OFFICIAL REPORT

$05 / 26 / 94 \quad 13: 14: 22$

Y-12 ANALYTICAL SERVICES ORGAHIZATION

PAGE 1 OF 1

SUBMITTER

Ingram, Edward Micha

DATE SAMPLED: 04/08/94 14:25:00

DATE RECEIVED: 04/08/94

SAMPLER: 029776
ADDRESS

Building 9115 MS 8219

DATE NEEDED: $04 / 22 / 94$

DATE COHPLETED: 04/22/94

SAMPLE DESCRIPTION: GRAB
CUSTOMER ID REO NO SAMPLE NO

E940980182

LOCATION: SOUTH WEST SAMPLE

PROJECT CODE:

FINAL APPROVAL:

COMMENTS: PINE RIDGE HEST REPEATER STATION

TEST: GRO TPH Gasoline Range Organics Including BTEX

PREP MTH: PROC MTH: SW846 8020 PHASE:

COMMENTS: PINE RIDGE WEST REPEATER SITE (2310-U)

FACILITY ID \# 0-010117

GRO Quantitation limit $100 \mathrm{ug} / \mathrm{L}$

BTEX Quantitation limit $10 \mathrm{ug} / \mathrm{L}$ per compound
REPLICATE: 1 STATUS: APPROVED

TIME ANALYZED: 04/21/94 19:55:00 APPROVER: E030124
CAS MUMBER

71432

100414

108883

1330207
DETERMINATION

Gasol ine Range Organics

Benzene

Ethylbenzene

Toluene

Xylene
DT

\begin{tabular}{l} 
RESULT \\
\hline 1600 \\
25 \\
80 \\
200 \\
390
\end{tabular}

\begin{tabular}{ll} 
CONFIDENCE & UNIT \\
\hline $\mathrm{mg} / \mathrm{kg}$ \\
$\mathrm{mg} / \mathrm{kg}$ \\
$\mathrm{mg} / \mathrm{kg}$ \\
$\mathrm{mg} / \mathrm{kg}$ \\
$\mathrm{mg} / \mathrm{kg}$
\end{tabular}




\section{UNCLASSIFIED}

OFFICIAL REPORT

\section{SUBMITTER}

Ingram, Edward Micha DATE SAMPLED: 04/08/94 14:29:00 DATE RECEIVED: 04/08/94 SAMPLER: 029776

\begin{tabular}{ll} 
ADDRESS & \\
\hline Building & $9115 \quad$ MS 8219 \\
$14: 29: 00$ & DATE NEEDED: $04 / 22 / 94$ \\
& DATE COMPLETED: 04/22/94 \\
& SAMPLE DESCRIPTION: GRAB
\end{tabular}

CUSTOMER ID

LOCATION: SOUTH EAST SAMPLE PROJECT COOE:

FINAL APPROVAL:
REQ NO SAMPLE NO E940980183

MTC STATUS 8403 APPROVED CHARGE \#: S2205F21 CASE: U03163

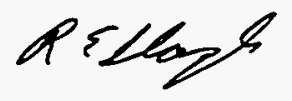

\section{COMMENTS: PINE RIDGE HEST REPEATER STATION}

TEST: GRO TPH Gasol ine Range Organics Including BTEX

PREP HTH:

COMMENTS: PINE RIDGE WEST REPEATER SITE (2310-U)

FACILITY ID \# 0-010117

GRO Quantitation limit $100 \mathrm{ug} / \mathrm{L}$

BTEX Quantitation limit $10 \mathrm{ug} / \mathrm{L}$ per compound
REPLICATE: 1

STATUS: APPROVED

TIME ANALYZED: 04/21/94 13:59:00

APPROVER: E030124

\begin{tabular}{|c|c|c|}
\hline CAS NUMBER & DETERMINATION & DT \\
\hline & Gasol ine Range Organics & \\
\hline 71432 & Benzene & \\
\hline 100414 & Ethylbenzene & \\
\hline 108883 & Toluene & \\
\hline 1330207 & xylene & \\
\hline
\end{tabular}

\begin{tabular}{|c|c|c|}
\hline RESULT & CONFIDENCE & UNIT \\
\hline 970 & & ug/kg \\
\hline $20 \mathrm{U}$ & & ug/kg \\
\hline 28 & & ug/kg \\
\hline 40 & & $\mathrm{ug} / \mathrm{kg}$ \\
\hline 220 & & $u g / k g$ \\
\hline
\end{tabular}




\section{UNCLASSIFIED}

OFFICIAL REPORT

\section{SUBMITTER}

Ingram, Edward Hicha DATE SAMPLED: 04/08/94 14:34:00 DATE RECEIVED: $04 / 08 / 94$ SAMPLER: 029776

CUSTOMER ID REQ NO

LOCATION: CENTER B STATION PROJECT CODE:

FINAL APPROVAL:

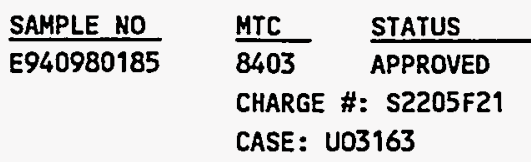
E940980185

MTC 8403 APPROVED CHARGE \#: S2205F21 CASE: $U 03163$

\section{COMMENTS: PINE RIDGE WEST REPEATER STATION}

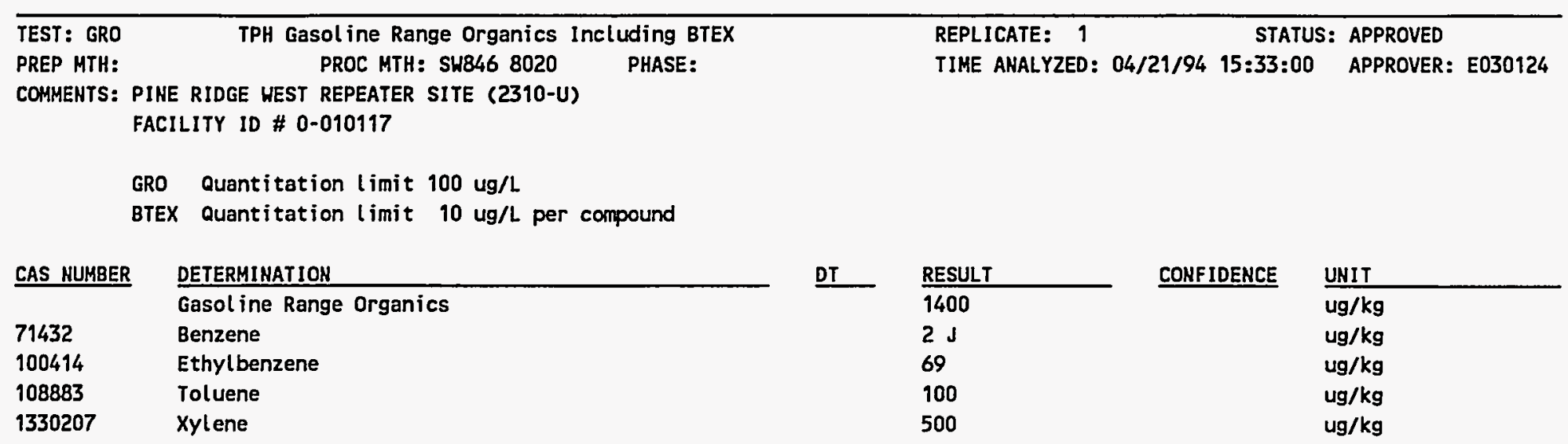




\section{UNCIASSIFIED}

OFFICIAL REPORT

05/26/94 13:18:08

Y-12 AHALYTICAL SERVICES ORGANIZATION

PAGE 1 OF 2

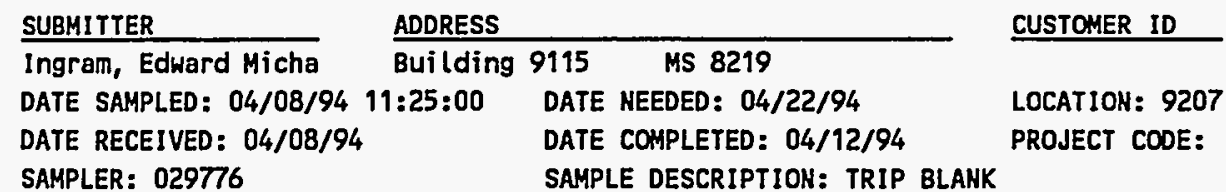

COMMENTS: TRIP BLANK FOR PINE RIDGE HEST REPEATER STATION SAMPLING JOB
REQ

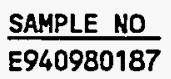

MTC STATUS 8403 APPROVED CHARGE \#: S2205F21 CASE: U03163

\begin{tabular}{lcll}
\hline TEST: VOA624 & Volatile Organics by GC/MS (EPA 624) & REPLICATE: 1 \\
PREP MTH: & PROC MTH: EPA 624 & PHASE: & TIME ANALYZED: 04/11/94 16:23:00
\end{tabular}

COMMENTS: PINE RIDGE WEST REPEATER SITE (2310-U)

FACILITY ID \# 0-010117

BTEX Quantitation limit $10 \mathrm{ug} / \mathrm{L}$ per compound

\begin{tabular}{|c|c|c|c|c|}
\hline CAS NUMBER & DETERMINATION & RESULT & CONFIDENCE & UNIT \\
\hline$\overline{74873}$ & Chloromethane & $10 \mathrm{U}$ & & $\overline{\mathrm{ug} / \mathrm{L}}$ \\
\hline 74839 & Bromomethane & 100 & & ug/L \\
\hline 75014 & Vinyl chloride & $10 U$ & & $u g / L$ \\
\hline 75003 & Chloroethane & $10 U$ & & ug/L \\
\hline 75694 & Trichlorof luoromethane & 100 & & ug/L \\
\hline 75092 & Methylene chloride & $10 U$ & & $u g / L$ \\
\hline 75354 & 1,1-Dichloroethene & $10 U$ & & $u g / L$ \\
\hline 75343 & 1,1-Dichloroethane & $10 u$ & & $u g / L$ \\
\hline 156605 & trans-1,2-Dichloroethene & 100 & & $u g / L$ \\
\hline 67663 & Chloroform & 100 & & $u g / L$ \\
\hline 107062 & 1,2-Dichloroethane & $10 u$ & & $u g / L$ \\
\hline 71556 & $1,1,1$-Trichloroethane & $10 U$ & & $u g / L$ \\
\hline 56235 & Carbon tetrachloride & $10 U$ & & $\mathrm{ug} / \mathrm{L}$ \\
\hline 75274 & Bromodichloromethane & 100 & & $u g / L$ \\
\hline 110758 & 2-Chloroethylvinyl ether & 100 & & $\mathrm{ug} / \mathrm{L}$ \\
\hline 78875 & 1,2-Dichloropropane & 100 & & $\mathrm{ug} / \mathrm{L}$ \\
\hline 10061015 & cis-1,3-Dichloropropene & $10 U$ & & $u g / L$ \\
\hline 79016 & Trichloroethene & $10 U$ & & $u g / L$ \\
\hline 124481 & Dibromoch loromethane & 100 & & $u g / L$ \\
\hline 79005 & 1,1,2-Trichloroethane & $10 U$ & & $u g / L$ \\
\hline 71432 & Benzene & 100 & & $u g / L$ \\
\hline 10061026 & trans-1,3-D ichloropropene & 100 & & $u g / L$ \\
\hline 75252 & Bromoform & 100 & & $\mathrm{ug} / \mathrm{L}$ \\
\hline 127184 & Tetrachloroethene & $10 U$ & & $u g / L$ \\
\hline 79345 & $1,1,2,2,-$ Tetrachloroethane & 100 & & $\mathrm{ug} / \mathrm{L}$ \\
\hline 108883 & Toluene & 100 & & $u g / L$ \\
\hline 108907 & Chlorobenzene & $10 U$ & & $u g / L$ \\
\hline
\end{tabular}

UNCLASSIFIED 


\section{UNCLASSIFIED}

\section{OFFICIAL REPORT}

SAMPLE E940980187

\section{4}

107028

107131
Ethylbenzene

Acrolein

Acrylonitrile
Y-12 ANALYTICAL SERVICES ORGANIZATION

PAGE 2 OF 2

$10 U$

100

100
ug/L

$\mathrm{ug} / \mathrm{L}$

ug/L

UNCIAASSIFIED 
DOE Y-12 PLANT CHAIN OF CUSTODY FORM

№ 20406

\begin{tabular}{|c|c|c|c|c|c|c|c|c|c|}
\hline A, & $\Phi_{\bar{I}}$ & zlen & & $69207 / 4-$ & & & & & \\
\hline $\begin{array}{l}\text { REQuISITION } \\
\text { NUMBER }\end{array}$ & 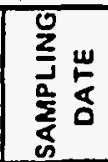 & 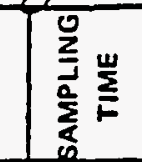 & 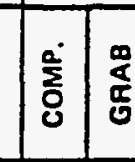 & 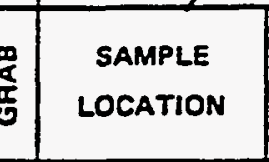 & \begin{tabular}{|l} 
No. OF \\
CoN. \\
TAMNER:
\end{tabular} & & & & REMARKS \\
\hline & & 1420 & & North West & 1 & & $x$ & & $E 940980176$ \\
\hline & & 1425 & & South West & 1 & & $x$ & & $E 940980182$ \\
\hline & & 1429 & & Sauth East & 1 & & $x$ & & $E 940980183$ \\
\hline & & 1432 & & Kenter A & 1 & & $x$ & & $E 940980184$ \\
\hline & & 1434 & & Cantes B & 1 & & $x$ & & $E 940980185$ \\
\hline & & 1436 & & North EAst & 1 & & $x$ & & E940980186 \\
\hline & & 1125 & & Trip Blank & 2 & $x$ & & & $E 940980187$ \\
\hline & & he & $\exists$ & thera & $T H$ & & & DEE WESt & EPEAER STRTOW \\
\hline & & & & & & & & & \\
\hline
\end{tabular}




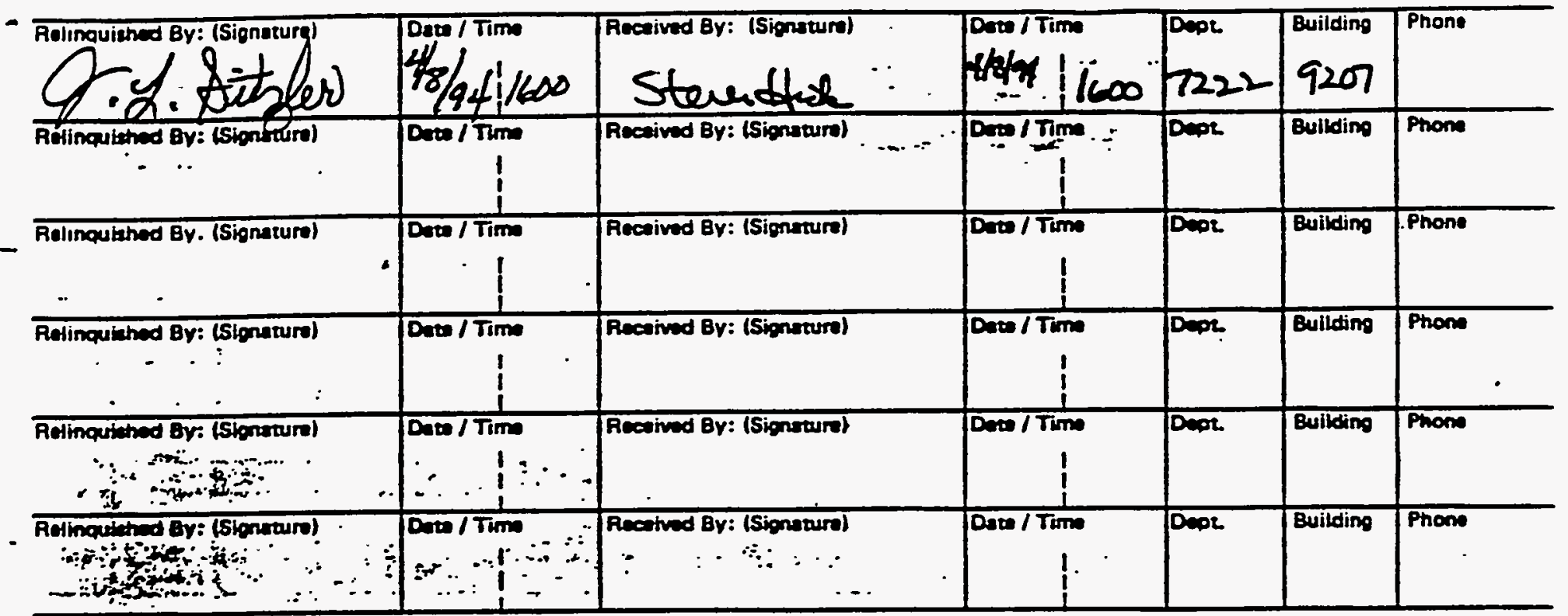

REMARKS:

AETURN TO: ENVIRONMENTAL MONITORING, 97041, MS - 1, 4300. 


\section{APPENDIX F \\ SECOND CONFIRMATORY SAMPLING LAB DATA SHEETS}




\section{UNCLASSIFIED}

OFFICIAL REPORT

\section{SUBMITTER}

Ingram, Edward Micha DATE SAMPLED: 05/05/94 13:05:00 DATE RECEIVED: 05/05/94

SAMPLER: 29776,22559

\section{ADDRESS}

Building 9115 MS 8219

DATE MEEDED: 05/06/94

DATE COMPLETED: 05/09/94 SAMPLE DESCRIPTION: GRAB

\section{CUSTOMER ID SW CORNER \\ SAMPLE NO E941250039} LOCATION: SOUTH WEST CORNER PROJECT CODE:
MTC STATUS 8403 APPROVED CHARGE \#: S2205F27 CASE: U03163

COMMENTS: PINE RIDGE WEST REPEATER STATION, SOUTH WEST CORNER

FINAL APPROVAL:

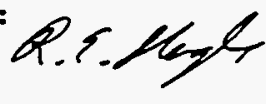

TEST: GRO TPH Gasoline Range Organics Including BTEX PREP MTH: PROC MTH: SH846 8020 PHASE:

COMMENTS: PINE RIDGE WEST REPEATER SITE (2310-U)

FACILITY ID \# 0-010117

GRO Quantitation limit $100 \mathrm{ug} / \mathrm{L}$

BTEX Quantitation limit $10 \mathrm{ug} / \mathrm{L}$ per compound
REPLICATE: 1

STATUS: APPROVED

TIME ANALYZED: 05/09/94 08:26:00 APPROVER: E030124

\section{CAS NUMBER}

DETERMINATION

Gasol ine Range Organics

71432

100414

108883

1330207
Benzene

Ethylbenzene

Toluene

Xylene
DT

\begin{tabular}{l} 
RESU \\
\hline $2 \mathrm{BJ}$ \\
$10 \mathrm{U}$ \\
$10 \mathrm{U}$ \\
$10 \mathrm{U}$
\end{tabular}

$10 \mathrm{U}$
CONFIDENCE UNIT

ug/L

ug/L

$\mathrm{ug} / \mathrm{L}$

ug/L

ug/L 


\section{UNCLASSIFIED}

OFFICIAL REPORT

05/26/94 13:16:07

Y-12 ANALYTICAL SERVICES ORGANIZATION

PAGE 1 OF 1

SUBMITTER

Ingram, Edward Micha

DATE SAMPLED: 05/05/94 14:05:00

DATE RECEIVED: 05/05/94

SAMPLER: 29776,22559

COMMENTS: PINE RIDGE WEST REPEATER STATION, NORTH EAST CORNER

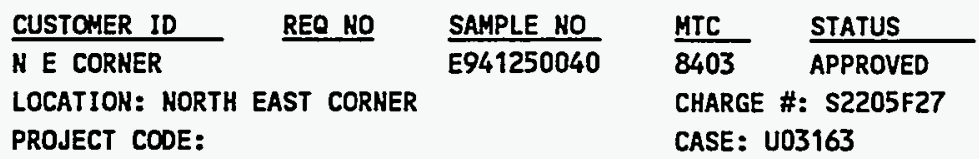

FINAL APPROVAL:

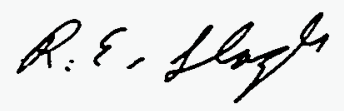

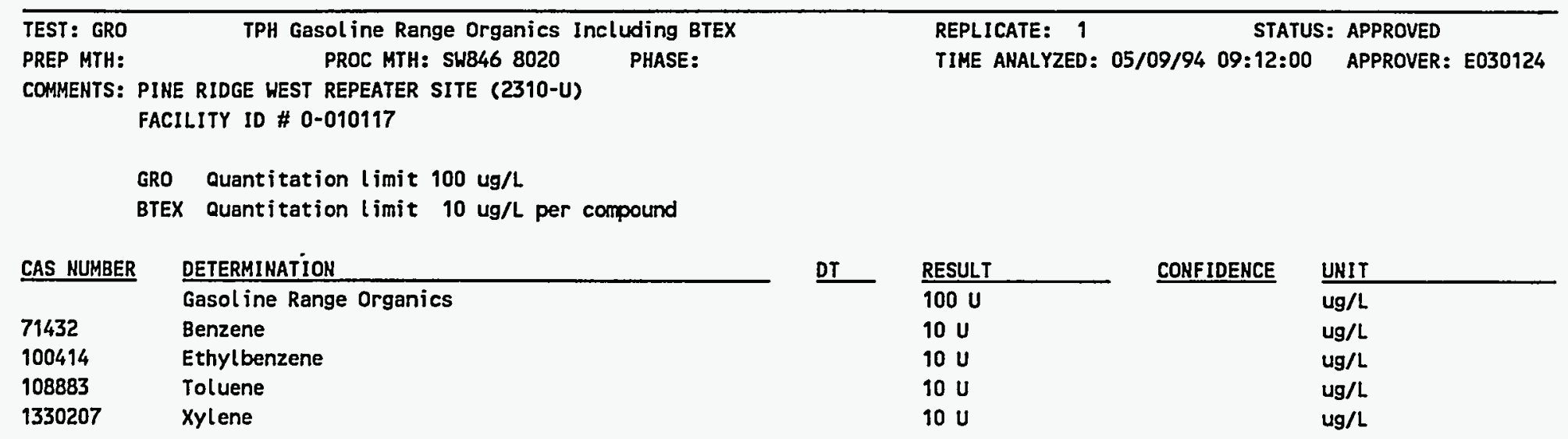

UNCLASSIFIED 


\section{UNCLASSIFIED}

OFFICIAL REPORT

\section{SUBHITTER}

Ingram, Edward Micha

ADDRESS

Building 9115 HS 8219

DATE SAMPLED: 05/05/94 14:00:00

DATE RECEIVED: 05/05/94

SAMPLER: 29776
CUSTOHER ID

TRIP BLANK

LOCATION: 9207

PROJECT CODE:
REO NO

SAMPLE NO E941250041

DATE COMPLETED: 05/09/94

SAMPLE DESCRIPTION: GRAB

FINAL APPROVAL:
MTC STATUS 8601 APPROVED CHARGE \#: S2211601 CASE: SQTOO1

COMMENTS: TRIP BLANK TIED TO E941250039 AND E941250040

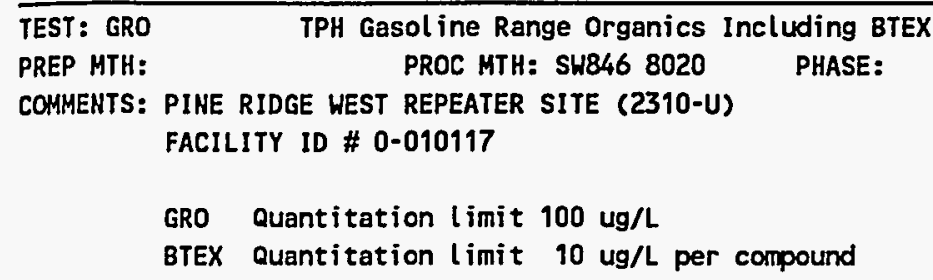

$10 \mathrm{U}$

$10 \mathrm{U}$

$10 \mathrm{U}$

$\begin{array}{ll}71432 & \text { Benzene } \\ 100414 & \text { Ethylbenzene } \\ 108883 & \text { Toluene } \\ 1330207 & \text { Xylene }\end{array}$

STATUS: APPROVED TIME ANALYZED: 05/09/94 07:43:00 APPROVER: E030124

TEST: V0A624 Volatile Organics by GC/MS (EPA 624)

\begin{tabular}{cc} 
CONFIDENCE & UNIT \\
\hline$u g / L$ \\
$u g / L$ \\
$u g / L$ \\
$u g / L$ \\
$u g / L$
\end{tabular}

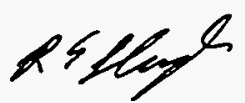

COMMENTS: PINE RIDGE WEST REPEATER SITE (2310-U)

FACILITY ID \# 0-010117

BTEX Quantitation limit $10 \mathrm{ug} / \mathrm{L}$ per compound THIS TEST WAS CANCELLED 
DOE Y-12 PLANT CHAIN OF CUSTODY FORM

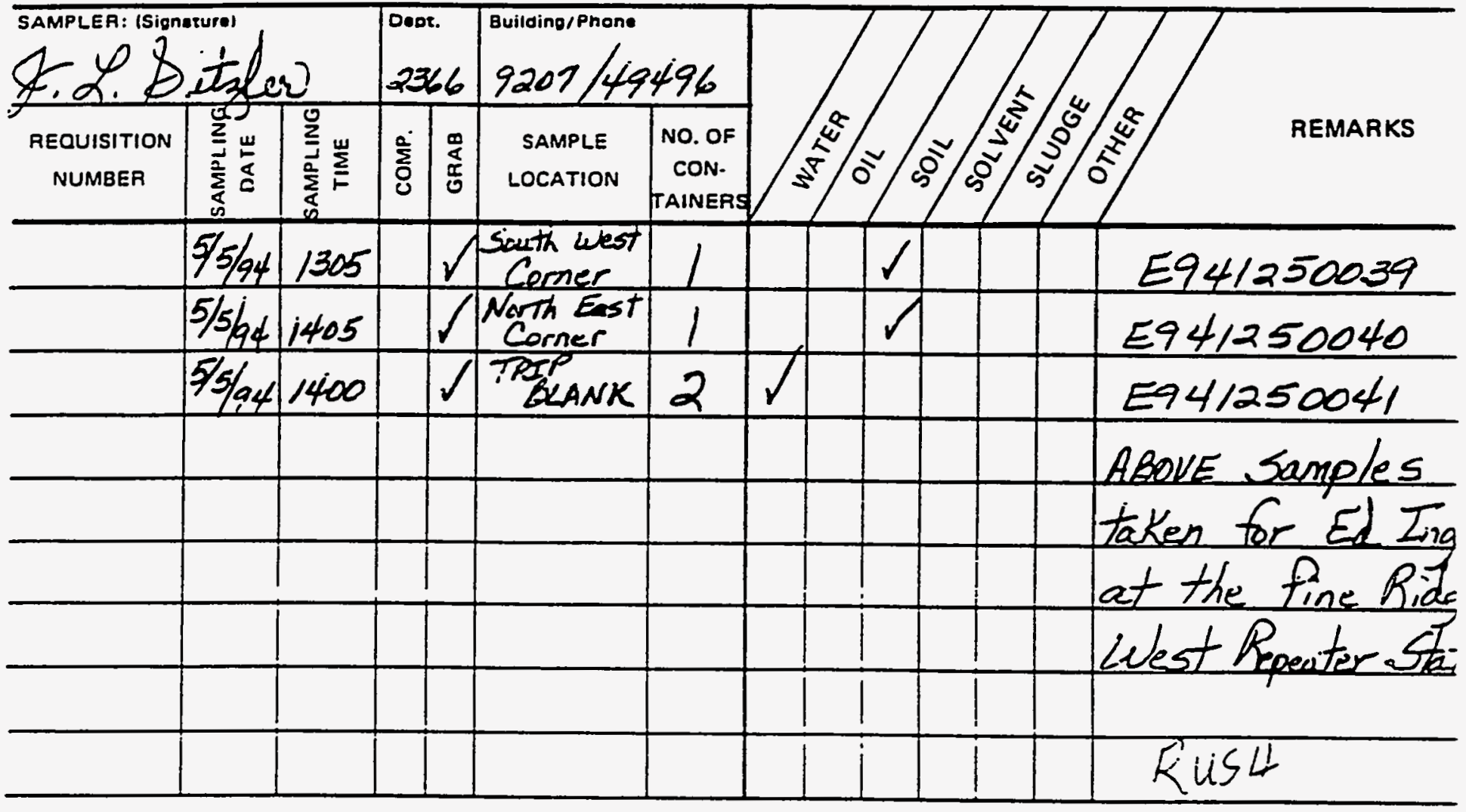

UCN.15487 $12 \quad 10.841$

Signatures Required on Back 


\begin{tabular}{|c|c|c|c|c|c|c|}
\hline Relınquished 8y: (Signatyre) & Date / Time & STgpryurel & Date / Time & Dept. & Building & Phone \\
\hline Rैelınquished By: (Sighrature) & $\begin{array}{r}\text { Date / Time } \\
1 \\
1 \\
\end{array}$ & Pecerved By: (Signatuta) & $\begin{array}{r}\text { Date / Time } \\
\vdots \\
1\end{array}$ & Dept. & Building & Phone \\
\hline Relinquisned By. (Signature) & Date / Time & Received Bv: (Signature) & Date / Time & Dedt. & Building & Phone \\
\hline Relınquished By: (Signature) & $\begin{array}{r}\text { Date / Time } \\
1 \\
1 \\
1\end{array}$ & Received 8y: (Signature) & $\begin{array}{r}\text { Dare / Time } \\
\\
\vdots \\
\end{array}$ & Dept. & Building & Phone \\
\hline Relinquished By: (Signature) & $\begin{array}{c}\text { Date / Time } \\
1 \\
1 \\
1\end{array}$ & Feceived By: (Signature) & $\begin{array}{r}\text { Date / Time } \\
! \\
\vdots\end{array}$ & Dept. & Building & Phone \\
\hline Relınquished By: (Signature) & $\begin{array}{r}\text { Date / Time } \\
\text { I }\end{array}$ & Received By: (Signature) & $\begin{array}{r}\text { Date / Time } \\
! \\
!\end{array}$ & Dept. & Building & Phone \\
\hline
\end{tabular}

REMARKS:

RETURN TO. ENVIRONMENTAL MONITORING, 9704-1, MS - 1. 4.3980. 
HEALTH, SAFETY, AND ENVIRONMENT ORGANIZATION

D.E. Bohrman (2)

L.L. Cunningham/E.M. Ingram

L.W. McMahon

File - EMD - RC

SAFEGUARDS, SECURITY, AND EMERGENCY PREPAREDNESS ORGANIZATION

R.L. Sampsel

ENVIRONMENTAL COMPLIANCE

ORGANIZATION

S.H. Welch

TENNESSEE DEPARTMENT OF ENVIRONMENT AND CONSERVATION

C. Head

E.C. Leming/J.D. Harless

\section{U.S. DEPARTMENT OF ENERGY}

E.M. Atkins

R.J. Spence/W.G. McMillian

S.R. Lankford

\section{A.K. Lee/DOE-OSTI (2) \\ Y-12 Central Files}

